\title{
Reduced survival of Black-throated Diver Gavia arctica chicks - an effect of changes in the abundance of fish, light conditions or exposure to mercury in the breeding lakes?
}

\author{
Försämrad överlevnad av storlommens Gavia arctica ungar - en effekt av \\ förändringar i fiskförekomst, ljusförhållanden eller kvicksilverexponering $i$ \\ häckningssjöarna?
}

MATS O. G. ERIKSSON

Abstract

The breeding success of Black-throated Diver Gavia arctica in Sweden has been monitored in the period 19942014. The production of young was in balance with the annual mortality, without any temporal trend. However, the percentage of broods with 2-3 chicks decreased significantly, indicating reduced survival of the unfledged chicks. Three plausible causes were investigated: abundance of fish, impaired water visibility, and exposure to methylmercury. There is no indication of any changes in abundance of the main prey fish, such as Perch Perca fluviatilis. Impaired light conditions have been recorded in lakes in South Sweden, but not in the central and northern parts, so increased difficulties in localising prey fish might have been a contributing factor but cannot fully explain any reduction in chick survival. Exposure to methylmercury, however, deserves further study. For Perch, which is the main prey in most breeding lakes, the average mercury levels in muscle tissue exceeds levels for proposed screening benchmarks, with reference to risk of behavioural aberrations or impaired reproduction in Common Loon Gavia immer in North America.

Mats O. G. Eriksson, MK Natur- och Miljökonsult, Tommeredsvägen 23, 43792 Lindome, Sweden; eriksson. tommered@telia.com.

Received 4 May 2015, Accepted 25 October 2015, Editor: S. Svensson

Recent population estimates indicate a population size of around 22000 pairs of Black-throated Diver Gavia arctica in Europe (outside of Russia), of which about $98 \%$ is found in the Nordic countries. During 2008-2012, 5300-7100 pairs were estimated to breed in Sweden and 12 000-13 000 pairs in Finland, with reference to the recent assessment of population status and trends of birds under Article 12 of the Birds Directive (http://bd.eionet. europa.eu/article12/). For Norway, the population is less than 5000 pairs, although no more precise recent estimates seem to be available (fact sheet from the Norwegian Species Information Centre, http://www.artsportalen.artsdatabanken.no/\#/Rodliste2010/Vurdering/Gavia+arctica/34353). Thus, the future of the Black-throated Diver in Europe is very much dependent on the management and development of the population in the Nordic countries.

The Black-throated Diver eats fish and it prefers breeding in clear, nutrient poor freshwater lakes with a species-poor fish fauna (Eriksson \& Paltto 2010). The prey is mostly caught in the breeding lakes, in contrast to the Red-throated Diver $G a$ - via stellata, which often breeds in small lakes and ponds without fish, but catches fish for the chicks from larger lakes with clear water or at sea up to a travelling distance of ca $10 \mathrm{~km}$, sometimes further.

The breeding populations of Black-throated Diver and Red-throated Diver in Sweden have been the target for voluntary-based surveys since 1994 (Projekt LOM, Eriksson 2010, 2014). For the Blackthroated Diver, the production of young has been in balance with the annual mortality, without any long-term temporal trend (Eriksson 2014). This is consistent with results from the Swedish Bird Survey, which indicate a slow but long-term increase in the size of the breeding population since the mid-1970s, although the trend might have levelled off in recent years (Green \& Lindström 2015). Despite the fact that levels and trends do not raise any immediate concern, there is nevertheless a worrying indication that the percentage of broods with 2-3 chicks has decreased since the mid 1990s (Figure 1, Eriksson 2014).

This might indicate a reduction in the survival of non-fledged chicks. Generally, divers lay two (rarely three) eggs. In most cases, both eggs hatch but often 


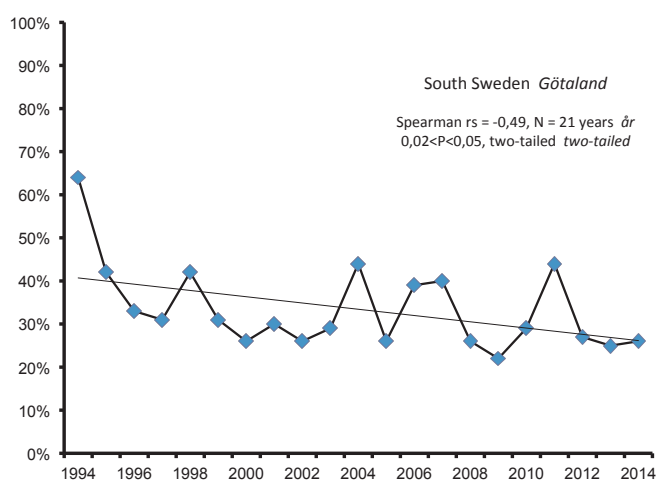

potentially overlapping explanations for the chicks' reduced survival have been studied:

- Changed abundance of prey fish: This aspect has been investigated using data from fish-sampling in freshwater lakes where a regular occurrence of breeding Black-throated Divers has been confirmed during the period 1994-2013.

- Changed light conditions in the lakes: In many lakes in Scandinavia, the content of dissolved organic compounds has increased over recent decades, with impaired light penetration as a consequence. There are different views on how to interpret these changes; e.g. a natural consequence of the recovery of lakes affected by acid precipitation during the mid $20^{\text {th }}$ century (e.g. Montheith et al. 2007, Erlandsson et al. 2008), or a climateinduced impact related to increasing temperature (e.g. Weyhenmeyer \& Karlsson 2009). In either case, this change might have affected the ability for the divers to find prey fish. Divers are visual predators and the choice of lakes for foraging is linked to the light penetration (e.g. Eriksson 1985, Eriksson \& Sundberg 1991, Kauppinen 1993), and the survival of non-fledged chicks is higher in lakes with good light conditions (Eriksson \& Paltto 2010). In this study, any changes in the light conditions in lakes regularly used by Blackthroated Diver during the period 1994-2013 have been investigated

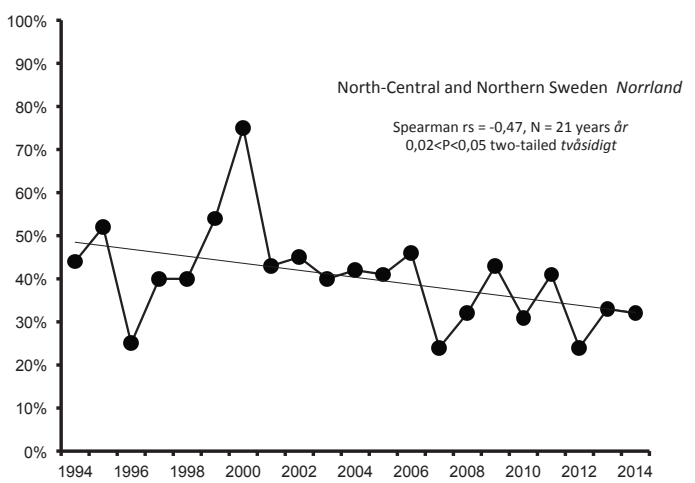

Figure 1. The percentage of broods with 2-3 large chicks, 1994-2014.

Procentandelen ungkullar med 2-3 stora ungar, 1994-2014.

only one of the chicks survives to fledge. The chicks are primarily fed with fish, but also with aquatic invertebrates during the first weeks after hatching. It is known from previous studies that the chicks' survival is largely dependent on the parents' success in providing them with small-sized fish (Jackson 2003). Thus, there are reasons to assume that any impaired survival of the chicks can be linked to the parents' ability to find prey fish for the chicks, or the quality of this prey. In this paper, three plausible and

- Exposure to mercury: Divers are top predators in the freshwater lake ecosystems and are thus susceptible to exposure to mercury and other elements via the intake of food (e.g. Scheuhammer et al. 2007 for an overview). Reports about increasing levels of mercury in fish since the 1990s, indicating that a long-term declining trend since the 1960s had been broken (Åkerblom \& Johansson 2008), have attracted some public attention, although the results have more recently been refuted (Åkerblom et al. 2014). Furthermore, the assessment of the trends in the mercury level in fish was primarily based on studies on Pike Esox lucius, although Perch Perca fluviatilis is a more relevant species for the purpose of this study as it is the most important prey for Black-throated Diver in many Scandinavian lakes. Trends in mercury levels are however, also difficult to assess for this fish species. Studies indicating an increasing trend in recent years (Danielsson et al. 2011) has to be balanced against information indicating higher contents in muscle samples from fish caught in Swedish lakes before 1996, compared to later, while the opposite seems to apply for Finland 
(Miller et al. 2013). In this study, the issue of exposure of Black-throated Divers to methylmercury via the intake of fish prey is discussed by relating information about the contents in Perch (Åkerblom \& Johansson 2008) to proposals of screening benchmarks to reflect risks for behavioural changes or impaired reproduction in Common Loon Gavia immer in North America (Burgess \& Meyer 2008, Depew et al. 2012).

\section{Material and methods}

\section{Study population and the survival of Black- throated Diver chicks}

A comprehensive overview of trends and levels in the breeding performance of the Black-throated Diver population in Sweden during 1994-2013 is given by Eriksson (2014), with the results presented separately for different parts of the country:

- South Sweden (Götaland) = Östergötland, Jönköping, Kronoberg, Kalmar, Blekinge, Skåne, Halland and Västra Götaland Counties.

- South-Central Sweden (Svealand) = Stockholm, Uppland, Södermanland, Värmland, Örebro, Västmanland and Dalarna Counties.

- North-Central and North Sweden (Norrland) = Gävleborg, Västernorrland, Jämtland, Västerbotten and Norrbotten Counties.

Background information of relevance for the present study is that the percentage of broods with $2-3$ chicks was $34 \%$ both in South and South-Central Sweden and $41 \%$ in North-Central and North Sweden during this period, and the numerical differences between the various parts of the country could not be verified by statistical significance. For the period 1994-2003 this percentage varied from $35 \%$ to $46 \%$ for the various parts of Sweden, compared to 30-36\% for the period 2004-2013 (table 3 in Eriksson 2014). The percentage of broods with 3 large chicks was $0.5 \%$, if pooling over all years and all parts of the country (page 33 in Eriksson 2010, updated with data for the period 2009-2013).

Thus, the parameter of specific interest for this purpose is the "percentage of broods with 2-3 large chicks", used as an index of the survival of chicks until fledged and a "large" chick being more than half the length of the adults and thus likely to fledge. Further details on the methods used for assessing the breeding result are given by Eriksson (2010, pages 80-81).

Regular checking of the number eggs in the nests has not been included in the field surveys, inter alia in order to reduce the risks of disturbing incubating birds and observer-related impact on the breeding performance. Thus, the information about clutch sizes is limited but on the basis of available data the percentage of nests with two eggs was compared for the periods 1994-2003 and 2004-2013, in order to confirm if any change in the percentage of broods with 2-3 large chicks might be a consequence of change in clutch size.

\section{Statistical analyses}

Temporal trends in the percentage of broods with 2-3 large chicks were investigated by calculating the Spearman rank correlation coefficient $r_{s}$. For the pairwise comparisons of data from the same lakes during the periods 1994-2003 and 2004-2013, the Wilcoxon's test for matched pairs was used (e.g. Fowler \& Cohen 1995). The results of the statistical tests are given in connection to relevant tables and figures.

\section{Selection of study lakes}

The material collected during the voluntary-based surveys in the period 1994-2013 includes information about the presence of breeding or territoryholding Black-throated Diver pairs in around 2350 lakes, which is equivalent to almost $10 \%$ of the approximately 24000 freshwater lakes larger than $0.1 \mathrm{~km}^{2}$ in Sweden. To make sure that the study included sites used regularly by breeding Blackthroated Diver it was restricted to only include lakes with information about breeding or territoryholding pairs in at least five years during the period 1994-2013. Some 500 lakes, or approximately 2\% of the lakes larger than $0.1 \mathrm{~km}^{2}$ in Sweden, met this criterion and for 153 of them information about fish abundance or light conditions was available (Appendix A for details).

\section{Abundance of fish}

For assessments of the abundance of fish, results from gill-net fishing done within the framework of national and regional monitoring http://www. slu.se/sjoprovfiskedatabasen) for the period 1994 2013 were used. To investigate any changes, pairwise comparisons were made in relation to fishing in the same lakes during the 10 -year periods 1994 2003 and 2004-2013.

The mean number of fish per catch effort was used as an indirect measure of the density of fish (Kinnerbäck 2001, no corrections were made with reference to potential net selectivity). The 
fish data was split up with reference to catches of Perch, cyprinid fish, salmonid fish, and Pike (see Table 2 in Eriksson \& Paltto 2010 for detailed information about the fish species in the different groups), bearing in mind that the production of young by Black-throated Diver has been found to be correlated only with the abundance of Perch rather than any other fish species (Eriksson \& Palto 2010). Catches of fish smaller than $22 \mathrm{~cm}$ were analysed separately as the chicks can rarely handle larger prey (Jackson 2003). Catches of Pike were analysed in order to check if the predation pressure by this species on newly hatched chicks had changed, with reference to previous studies indicating this risk (e.g. Lehtonen 1970, Jackson 2003, see also Dessborn et al. 2011 with reference to ducks).

Among the lakes selected for this study, results from at least one fish sampling each during the periods 1993-2003 and 2004-2013 were available from 40 lakes in South Sweden and 10 lakes in South-Central Sweden, but only one lake in North-Central and North Sweden. Analyses were thus only carried out for South and South-Central Sweden (Appendix B for details).

\section{Light conditions in the lakes}

Data was primarily collected from the national monitoring of lakes (http://infol.ma.slu.se/ db.html, Wilander et al. 2003 for methods etc) with complementary information for some lakes in the County of Västra Götaland. To investigate any changes, pair-wise comparisons were made using results from the same lakes over the 10 -year periods 1994-2003 and 2004-2013.

Absorbance was used as the main measure of light penetration. The light penetration is primarily dependent on the contents of dissolved organic compounds and turbidity. In the Swedish environmental monitoring programme the absorbance of light with a the wavelength of $420 \mathrm{~nm}$ has been used as a standardised parameter, and a brown colour of the water can be detected by the naked eye at circa $0.2 \mathrm{f}_{420 / 5}$ in lakes with a high contents of humic substances. Information about absorbance for the periods 1994-2003 and 2004-2013 was available for 70 lakes in South Sweden, 43 lakes in South-Central Sweden and 11 lakes in NorthCentral and North Sweden.

Information available about Secchi disc transparency was used in parallel, as this was regularly recorded when fish sampling was carried out. Data was available for 22 lakes in South Sweden, 7 lakes in South-Central Sweden but only one lake in North-Central and North Sweden.

\section{Mercury contents in fish and Black-throated Diver eggs}

For a discussion in relation to the risks linked to exposure to mercury, previously published information regarding the contents in Black-throated Diver eggs (Eriksson \& Lindberg 2005) and freshwater fish (e.g. Åkerblom \& Johansson 2008) was used.

\section{Results}

\section{Survival of Black-throated Diver chicks}

The percentage of broods with 2-3 chicks decreased significantly in all parts of Sweden during the period 1994-2014 (Figure 1), which is consistent with the overall lower percentage reported during the period 2004-2013 compared to 1994-2003 (table 3 in Eriksson 2014).

The decreased percentage of broods with 2-3 large chicks cannot be ascribed to any decline in clutch size. It is unlikely that the percentage of egg clutches with 2 eggs has changed during the study period. Although the number of nests with information about clutch size is small, pooling the available information for the periods 1994-2003 and 2004-2013, respectively, did not indicate any change; the percentage of nests with 2 eggs was $82 \%$ for the period 1994-2003 (45 nests in total) and $79 \%$ for 2004-2013 (11 nests). No clutches with 3 eggs have been recorded, and they can be expected to constitute only a small proportion (2.3\% in a study from Finland during the 1960 s, Lehtonen 1970).

\section{Abundance of fish}

There were no indications that the total abundance of fish has changed in the breeding lakes in South and South-Central Sweden, nor the abundance of Perch, which is the Black-throated Diver's main prey species in many lakes, although the results of gill-net fishing indicated substantial changes in individual lakes. The only exception was a decreased abundance of cyprinid fish in South-Central Sweden (Table 1, Figure 2, details in Appendix B). This result applies both for total catches and small-sized fish $(<22 \mathrm{~cm})$. 
Table 1. Number of fish per catch effort per lake with gill-nets.

Antal fiskar per fångsansträngning och sjö vid provfisken med översiktsnät.

\begin{tabular}{|c|c|c|c|c|c|c|c|c|c|c|c|c|}
\hline \multirow{4}{*}{$\begin{array}{l}\text { Number of lakes } \\
\text { Antal sjöar }\end{array}$} & \multicolumn{4}{|c|}{$\begin{array}{l}\text { South Sweden } \\
\text { Götaland }\end{array}$} & \multicolumn{4}{|c|}{$\begin{array}{l}\text { South-Central Sweden } \\
\text { Svealand }\end{array}$} & \multicolumn{4}{|c|}{$\begin{array}{l}\text { Total } \\
\text { Totalt }\end{array}$} \\
\hline & \multicolumn{4}{|c|}{40} & \multicolumn{4}{|c|}{10} & \multicolumn{4}{|c|}{50} \\
\hline & \multicolumn{2}{|c|}{$\begin{array}{l}\text { All fish } \\
\text { All fisk }\end{array}$} & \multicolumn{2}{|c|}{$\begin{array}{l}\text { Fish }<22 \mathrm{~cm} \\
\text { Fisk }<22 \mathrm{~cm}\end{array}$} & \multicolumn{2}{|c|}{$\begin{array}{l}\text { All fish } \\
\text { All fisk }\end{array}$} & \multicolumn{2}{|c|}{$\begin{array}{l}\text { Fish }<22 \mathrm{~cm} \\
\text { Fisk }<22 \mathrm{~cm}\end{array}$} & \multicolumn{2}{|c|}{$\begin{array}{l}\text { All fish } \\
\text { All fisk }\end{array}$} & \multicolumn{2}{|c|}{$\begin{array}{l}\text { Fish }<22 \mathrm{~cm} \\
\text { Fisk }<22 \mathrm{~cm}\end{array}$} \\
\hline & $\begin{array}{c}1994- \\
2003\end{array}$ & $\begin{array}{r}2004- \\
2013\end{array}$ & $\begin{array}{c}1994- \\
2003\end{array}$ & $\begin{array}{r}2004 \\
2013\end{array}$ & $\begin{array}{c}1994- \\
2003\end{array}$ & $\begin{array}{r}2004 \\
2013\end{array}$ & $\begin{array}{c}1994- \\
2003\end{array}$ & $\begin{array}{c}2004- \\
2013\end{array}$ & $\begin{array}{r}1994- \\
2003\end{array}$ & $\begin{array}{r}2004 \\
2013\end{array}$ & $\begin{array}{c}1994- \\
2003\end{array}$ & $\begin{array}{r}2004 \\
2013\end{array}$ \\
\hline $\begin{array}{l}\text { Total catch } \\
\text { Hela fångsten }\end{array}$ & 30.8 & 28.9 & 28.5 & 26.5 & 35.1 & 34.3 & 30.7 & 31.0 & 31.7 & 30.0 & 28.6 & 27.4 \\
\hline $\begin{array}{l}\text { Perch Perca fluviatilis } \\
\text { Abborre }\end{array}$ & 16.9 & 15.6 & 15.2 & 14.5 & 12.4 & 18.8 & 11.3 & 17.6 & 16.0 & 16.3 & 14.4 & 15.1 \\
\hline $\begin{array}{l}\text { Cyprinid fish } \\
\text { Mörtartad fisk }\end{array}$ & 11.2 & 10.9 & 10.6 & 10.1 & 20.0 & $12.5^{\mathrm{a}}$ & 19.4 & $11.6^{\mathrm{a}}$ & 13.0 & 11.2 & 12.3 & 10.4 \\
\hline $\begin{array}{l}\text { Salmonid fish } \\
\text { Laxartad fisk }\end{array}$ & 1.1 & 0.8 & 1.0 & 0.8 & 0.6 & 1.1 & 0.6 & 1.1 & 1.0 & 0.9 & 0.9 & 0.9 \\
\hline $\begin{array}{l}\text { Pike Esox lucius } \\
\text { Gädda }\end{array}$ & 0.2 & 0.2 & - & - & 0.1 & 0.1 & - & - & 0.2 & 0.2 & - & - \\
\hline
\end{tabular}

a $\mathrm{P}<0,01$, two-tailed. No other differences could be established with statistical significance (Wilcoxon's test for matched pairs).

${ }^{a} P<0,01$, tvåsidigt. Inga andra skillnader kunde fastställas med statistisk signifikans (Wilcoxons test avseende matchade par).

\section{Light conditions in the lakes}

Both absorbance and Secchi disc transparency indicated that there has been impaired light penetration in South Sweden since the mid-1990s, but there were no indications of similar changes in the remaining part of Sweden. Absorbance has increased by $16 \%$ on average in the lakes in South Sweden while it had remained at the same level in the other parts of the country (Table 2, Figure 3,
Appendix C for details). Secchi disc transparency decreased by $23 \%$ on average, from $3.9 \mathrm{~m}$ to 3.0 $\mathrm{m}$, while it remained at the same level, 3.5-3.6 m in South-Central Sweden (Table 2, Figure 4, Appendix $\mathrm{C}$ for details).

\section{Discussion}

Most likely and with reference to previous studies (Jackson 2003), the decreased percentage of

Table 2. Light conditions. Significance tested by Wilcoxon's test for matched pairs; P two-tailed. Ljusförhållanden. Signifikansen tested med Wilcoxons test avseende matchade par; P tvåsidigt

\begin{tabular}{lllll}
\hline & & $\begin{array}{l}\text { South Sweden } \\
\text { Götaland }\end{array}$ & $\begin{array}{l}\text { South-Central Sweden } \\
\text { Svealand }\end{array}$ & $\begin{array}{l}\text { North-Central and } \\
\text { North Sweden } \\
\text { Norrland }\end{array}$ \\
\hline $\begin{array}{l}\text { Absorbance, } f_{420 / 5} \\
\text { Absorbans, } f_{420 / 5}\end{array}$ & $\begin{array}{l}\text { 1994-2003 } \\
\text { 2004-2013 }\end{array}$ & 0.12 & 0.09 & 0.10 \\
& $\begin{array}{l}\text { Number of lakes } \\
\text { Antal sjöar }\end{array}$ & 70 & 0.09 & 0.11 \\
& $\mathrm{P}$ & 0.004 & 43 & 11 \\
\hline Transparency, $\mathrm{m}$ & 1994-2003 & 3.9 & N.S. ej sign. & N.S. ej sign. \\
\hline Siktdjup, $m$ & 2004-2013 & 3.0 & 3.5 & 4.2 \\
& $\begin{array}{l}\text { Number of lakes } \\
\text { Antal sjöar }\end{array}$ & 22 & 7 & 3.5 \\
& $\mathrm{P}$ & 0.002 & N.S. ej sign. & 1 \\
& & & Not tested Ej testad \\
\hline
\end{tabular}



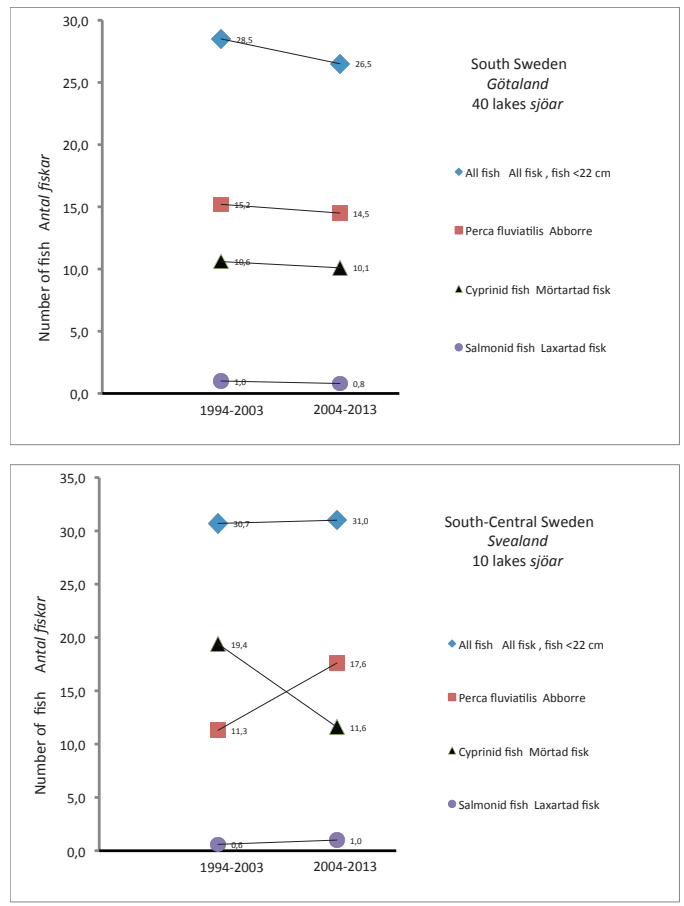

Figure 2. Mean number of small-sized fish $(<22 \mathrm{~cm})$ per catch effort and lake. The outcome of pair-wise comparisons for the periods 1994-2003 and 2004-2013 with Wilcoxon's test for matched pairs is shown in Table 1.

Medelantal småvuxna fiskar $(<22 \mathrm{~cm})$ per nätansträngning och sjö. Resultatet av parvisa test för perioderna 1994-2003 och 2004-2013, med Wilcoxons test avseende matchade par, redovisas $i$ Tabell 1 .

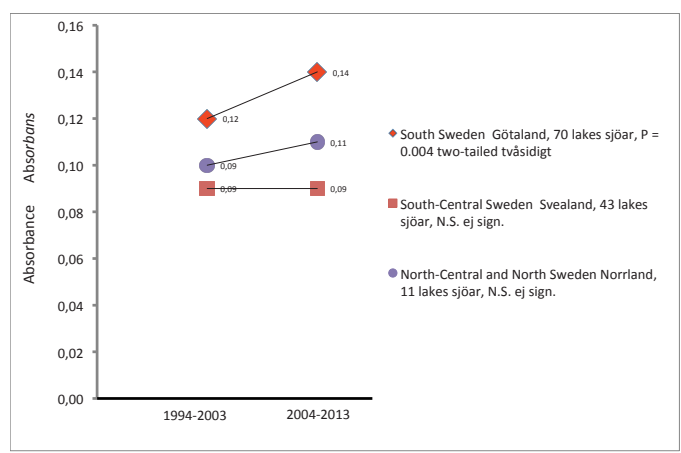

Figure 3. Absorbance, $\mathrm{f}_{420 / 5}$, mean value per lake. Two-tailed $\mathrm{P}$-values refer to pair-wise comparisons for the periods 1994-2003 and 2004-2013 with Wilcoxon's test for matched pairs.

Absorbans, $f_{420 / 5}$ medelvärde per sjö. Tvåsidiga P-värden avser parvisa test för perioderna 1994-2003 och 2004-2013 med Wilcoxons test avseende matchade par.

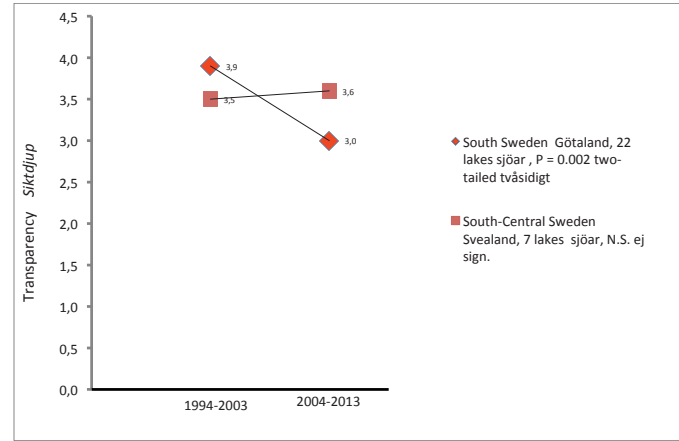

Figure 4. Mean Secchi disc transparency, m, mean value per lake. Two-tailed P-values refer to pair-wise comparisons for the periods 1994-2003 and 2004-2013 with Wilcoxon's text for matched pairs.

Siktdjup, m, medelvärde per sjö. Tvåsidiga P-värden avser parvisa test för perioderna 1994-2003 och 2004-2013 med Wilcoxons test avseende matchade par.

broods with 2-3 large chicks indicates an impaired survival until they are fledged. Thus far, the decreased percentage of broods with $2-3$ chicks has not resulted in any overall decline in the production of young, most likely because failures during incubation, such as predation and flooded nests have been the factors primarily affecting the breeding success (Table 3 in Hake et al. 2005) and thus any decreased percentage of broods with 2-3 chicks has to be substantial, if it is to have an impact on the overall breeding success. Furthermore and for South Sweden, the percentage of successful breeding attempts, resulting in at least one large chick, increased during the period 2004-2013 (table 3 in Eriksson 2014), which might indicate that an improved hatching success may have compensated for the increased loss of non-fledged chicks. Nevertheless, the decreased percentage of broods with 2-3 large chicks should not be ignored. If this trend continues, it might influence the overall breeding performance and in addition, the reduced chick survival may indicate a more widespread environmental disturbance, affecting a large proportion of the freshwater lakes in Sweden.

There were however, no indications that the decreased percentage in broods with $2-3$ chicks could be directly linked with changes in the abundance of fish. Bearing in mind that the breeding performance of Black-throated Diver has been shown to correlate only with the abundance of Perch rather than any other species of fish (Eriksson \& Paltto 2010), it is noteworthy that the abundance of Perch had not changed over the study period (Table 1, Figure 2). In addition, there were no indications 
that the abundance of Pike had changed, so it is not likely the predation pressure by Pike on newly hatched chicks had increased.

It is uncertain whether or not change in the light conditions is a main cause. It is certain that light penetration has decreased in the breeding lakes in South Sweden but not further north (Table 2, Figures 3 and 4), although the percentage of broods with 2-3 chicks has also declined in the remaining parts of Sweden (Figure 1). For South Sweden however, impaired light penetration might have strengthened any impact on the chick survival caused by any other factor.

Due to the fact that there were no unambiguous indications that the abundance of fish or changed light conditions might have affected the survival of chicks, exposure to mercury deserves further attention. This issue has been extensively studied with reference to Common Loon in North America (e.g. Scheuhammer et al. 2007). Studies in captivity of Common Loon chicks exposed to various levels of methylmercury injected in eggs or in the diet provided to chicks indicate that exposure to levels likely to occur in nature have consequences on the chicks' behavior (Kenow et al. 2010, 2011).

For Sweden, higher concentrations of mercury were found in Black-throated Diver eggs from pairs fishing in lakes affected by acidification during the 1980 s and 1990s, compared with other lakes although the concentrations were judged to be below the level where there was a risk of any impact on reproduction (Eriksson \& Lindberg 2005).

Current information about mercury levels in muscle tissue samples from Perch collected in freshwater lakes in Sweden indicate median values of 0.14 ppm in small-sized fish, primarily feeding on plankton, $0.20 \mathrm{ppm}$ in medium-sized fish of $12-18 \mathrm{~cm}$ length and $0.34 \mathrm{ppm}$ in larger Perch that primarily predate on other fish (Akerblom \& Johansson 2008). These figures should be related to indications of a $50 \%$ reduction in the productivity of Common Loon at a mercury level of 0.21 ppm in fish and a complete failure in production at $0.41 \mathrm{ppm}$ (Burgess \& Meyer 2008). Furthermore, benchmarks for screening various levels of risks of behavioural aberrations and impaired or failed reproduction in Common Loon have been proposed at the levels of $0.1,0.18$ and $0.4 \mathrm{ppm}$, respectively (Depew et al. 2012). Earlier studies have also shown an impaired reproduction in Common Loon that has been linked to mercury levels of $0.3-0.4 \mathrm{ppm}$ in the prey fish (Barr 1986). It is thus very likely that Black-throated Divers breeding in freshwater lakes in Sweden have been exposed to mercury at levels where the risk of reproductive impairment cannot not be excluded, even if it is unclear about any trends in the concentrations of methylmercury in Perch caught in Swedish lakes (Danielsson et al. 2011, Miller et al. 2013). Thus, and although this study does not provide any final conclusions about the reasons behind any reduced survival of Black-throated Diver chicks, it nevertheless indicates that risks related to exposure to mercury should be prioritised for further research.

High mercury levels in the environment have been an issue of concern for more than fifty years. Initially, the problems were related to the use of mercury in fungicides in agriculture and in the pulp industry, and as far back as the 1960s high levels of methylmercury in fish was reported (e.g. Johnels et al. 1967, Ackefors 1971 with reference to Sweden). With the successful restriction of the use of mercury as fungicide-treatment, this source has been kept under control. More recently, focus has been directed towards the exposure of freshwater organisms to mercury that can be traced to airborne pollutants, emissions from fossil fuels and leaching of mercury deposited in terrestrial environments into aquatic habitats (e.g. Skyllberg 2003, Evers et al. 2007). In single lakes, the content of mercury in fish is related to a complex of factors, of which water chemistry and land-use in the catchment area are the most important. Studies in North America suggest that the risk for top predators is substantial in nutrient-poor lakes, with $\mathrm{pH}$ values below 6.0 in combination with low alkalinity and high contents of dissolved organic carbon (Driscoll et al. 2007, Evers et al. 2007). With reference to these indicators, almost $10 \%$ of the Black-throated Diver breeding lakes and more than $30 \%$ of the fishing lakes used by Red-throated Diver have been judged to be at risk for high exposure to methylmercury related to leaching from forest and wetland habitats in the catchment areas (Eriksson \& Paltto 2010).

\section{Proposal for further actions}

A main conclusion from this study is that risks related to exposure to mercury should be prioritised in the management of fish and bird populations in freshwater lakes in Sweden. The decreased percentage of broods with 2-3 chicks may indicate an environmental disturbance with wider implications, bearing in mind that mercury concentrations in Perch exceed the current EU environmental quality standard (EC Directive 2008/105/EC, http://eurlex.europa.eu/LexUriServ/LexUriServ.do?uri=OJ: L:2008:348:0084:0097:EN:PDF, see also Miller et 
al. 2013) in many Swedish freshwater lakes, and that concentrations exceed limits proposed for human consumption in single lakes (Danielsson et al. 2011). The absence of any public debate about the quality of freshwater fish, as food both for humans and birds, in contrast to the discussions on the same issues during the 1960s and 1970s is both remarkable and worrying.

However, there is room for initiatives, which might include:

- Complementary collection and analyses of eggs of Black-throated Diver, bearing in mind that no analyses of eggs collected after 1997 are available making it impossible to investigate any recent trends.

- Establish a standardised monitoring of the mercury concentrations in Black-throated Diver eggs, under strictly supervised conditions in order to avoid any negative impact on the breeding performance. This should make it possible to better monitor any impact on top predators in the freshwater ecosystems, humans as well as divers and other fish-eating bird species, being exposed to methylmercury via the intake of fish. Studies of Common Loon in North America indicate that eggs, feathers and blood samples are good indicators of geographical patterns and trends in the bioavailability of methylmercury for top predators in freshwater habitats (e.g. Evers et al. 2003, 2008). Furthermore, such a project is in line with a proposal in a recent review of the national contaminant monitoring in aquatic habitats in Sweden, e.g. to prioritise surveys of concentrations and impact on top predators in freshwater environments (Naturvårdsverket 2014).

- Continued efforts to reduce the use of fossil fuels, with reference to North American studies that also indicate that local and regional restrictions may provide positive effects (Driscoll et al. 2007).

- Better understanding of the local and regional impact on single lakes by forestry and other kinds of land use in the catchment area (e.g. Bishop 2013), to make it possible to draft recommendations for foresters and other stakeholders on how to adjust land-use in order to minimise the local impact on freshwater habitats. On the basis of current knowledge, the relevant public authorities should consider developing practical advice.

This paper has focused on the impact of various factors that might be operating during the breeding season, although exposure outside the breeding areas, e.g. during migration and the winter, may also affect the breeding performance, as has been shown for Red-throated Divers in Alaska (Schmutz et al. 2009). Verified reduction in reproductive success may be a combined effect of exposure to various kinds of elements, at different sites and times of the year.

\section{Acknowledgments}

This study is primarily based on results from the voluntary-based surveys of the breeding performance of Black-throated Diver and Red-throated Diver in Sweden, Projekt LOM; http://www.projekt-lom. com. During 1994-1999, the project was organised jointly by The Swedish Society for Nature Conservation (Svenska Naturskyddsföreningen) and the Swedish Ornithological Union (Sveriges Ornitologiska Förening), and after that the work has continued by an independent NGO. Since the start in 1994, more than 400 people have contributed with information for at least one year, and during recent years around 140 persons have taken an active part in the field-surveys. Complementary information has been collected from the The Swedish Species Reporting System, https://www.artportalen.se/. The Alvin Fund and the Swedish section of the World Wildlife Fund (WWF Sverige) have given financial support in single years. An anonymous reviewer gave comments to a previous draft version.

Information about water chemistry has primarily been collected from the national monitoring of freshwater lakes via the web-site of the Department of Aquatic Sciences and Assessments at the Swedish University for Agricultural Sciences, http:// infol.ma.slu.se/db.html. Information about fish stocks in various lakes has been collected from the national register of fish sampling - NORS, http:// www.slu.se/sjoprovfiskedatabasen, hosted by the Department of Aquatic Resources at the Swedish University for Agricultural Sciences.

\section{References}

Ackefors, H. 1971. Mercury pollution in Sweden with special reference to conditions in the water habitat. Proceedings of the Royal Society of London Series B - Biological Sciences 177: 365-387; http://rspb.royalsocietypublishing.org/content/177/1048/365.

Barr, J.F. 1986. Population dynamics of the Common Loon (Gavia immer) associated with mercury-contaminated waters in northwestern Ontario. Canadian Wildlife Service Occasional Paper 56.

Bishop, K. 2013. Skogsbrukets effekter på kvicksilverutlakningen. Page 22 in Laudon, H (ed.) Mark och vatten. Rapport från Future Forests 2009-2012. Future Forests Rapport 2013:3. Sveriges Lantbruksuniversitet, Umeå; http:// 
www.slu.se/Global/externwebben/centrumbildningarprojekt/futureforests/FFRapport_Mark\%20och\%20vatten\%202013-08-13.pdf.

Burgess, N.M. \& Meyer, M.W. 2008. Methylmercury exposure associated with reduced productivity in common loons. Ecotoxicology 17: 83-91; http://link.springer.com/ article/10.1007\%2Fs10646-007-0167-8.

Danielsson, S., Hedman, J., Miller, A. \& Bignert, A. 2011. Mercury in Perch from Norway, Sweden and Finland geographical patterns and temporal trends. Swedish $\mathrm{Mu}$ seum of Natural History Report 8:2011; http://www.nrm. se/download/18.42129f1312d951207af800030436/1367 705038388/8_2011+Danielsson+et+al+Mercury+in+per ch+2011.pdf.

Depew, D.C., Basu, N., Burgess, N.M., Campbell. L.M., Evers, D.C., Grasman, K.A. \& Scheuhammer, A.M. 2012. Derivation of screening benchmarks for dietary methylmercury exposure for the Common Loon (Gavia immer): rationale for use in ecological risk assessment. Environmental Toxicology and Chemistry 31: 2399-2407; http://onlinelibrary.wiley.com/doi/10.1002/etc.1971/abstract;jsessionid= C027908DDE07CC5E315F334028A2948B.f03t04.

Dessborn, L., Elmberg, J. \& Englund, G. 2011. Pike predation affects breeding success and habitat selection of ducks. Freshwater Biology 56: 579-589; http://onlinelibrary.wiley.com/doi/10.1111/j.1365-2427.2010.02525.x/abstract.

Driscoll, C.T., Young-Ji, H., Chen, C., Evers, D., Lambert, K.F., Holsen, T.M., Kamman, N.C. \& Munson, R.K. 2007. Mercury contamination in forest and freshwater ecosystems in northeastern United States. Bioscience 27: 17-28; http://surface.syr.edu/cgi/viewcontent. cgi? article $=1003 \&$ context $=$ cie.

Eriksson, M.O.G. 1985. Prey detectability for fish-eating birds in relation to fish density and water transparency. Ornis Scandinavica 16: 1-7.

Eriksson, M.O.G. 2010. Storlommen och smålommen i Sverige - populationsstatus, hotbild och förvaltning. Sveriges Ornitologiska Förening, Stockholm och Svenska LOM-föreningen / Projekt LOM, Göteborg; http://www. projekt-lom.com/LOM-rapporten.pdf.

Eriksson, M.O.G. 2014. Projekt LOM 20 år - 1994-2013. Pages 33-47 in SOF 2014. Fågelåret 2013. Sveriges Ornitologiska Förening, Stockholm; http:/www.projektlom.com/Projekt.LOM.FAR.2013.pdf.

Eriksson, M.O.G. \& Lindberg, P. 2005. Mercury exposure to Red-throated Diver Gavia stellata and Black-throated Diver Gavia arctica in Sweden. Ornis Svecica 15: 1-12; in Swedish, summary in English; http://www.projekt-lom. com/Ornis\%20Svecica $\% 2015 \% 201-12$.pdf.

Eriksson, M.O.G. \& Paltto, H. 2010. Water chemistry and the composition of fish stocks in the breeding lakes of Black-throated Diver Gavia arctica, and a comparison with the fishing lakes of Red-throated Diver Gavia stellata. Ornis Svecica 20: 3-30; in Swedish, summary in English; http://www. projekt-lom.com/Ornis\%20Svecica\%2020\%203-10.pdf.

Eriksson, M.O.G. \& Sundberg, P. 1991. The choice of fishing lakes by Red-throated Diver Gavia stellata and Blackthroated Diver $G$. arctica during the breeding season in south-west Sweden. Bird Study 38: 153-144.

Erlandsson, M., Buffam, I., Fölster, J., Laudon, H., Temnerud, J., Weyhenmeyer, G.A. \& Bishop, K. 2008. Thirtyfive years of synchrony in the organic matter concentrations of Swedish rivers explained by variation in flow and sulphate. Global Change Biology 14: 1191-1198; http://onlinelibrary.wiley.com/doi/10.1111/j.13652486.2008.01551.x/abstract.

Evers, D.C., Taylor, K.M., Major, A., Taylor, R.J., Poppenga, R.H. \& Scheuhammer, A.M. 2003. Common loon eggs as indicators of methylmercury availability in North America. Ecotoxicology 12: 69-81; http://www.fws.gov/ uploadedFiles/Evers2003.pdf.

Evers, D.C., Hart, Y.-J., Driscoll, C.T., Kamman, N.C., Goodale, M.W., Lambert, K.F., Holsen, T.M., Chen, C., Clair, T.A. \& Butler, T. 2007. Biological mercury hotspots in northeastern United States and southeastern Canada. Bioscience 27: 29-43; http://www.niehs.nih.gov/research/ supported/assets/docs/a_c/bioscience_508.pdf

Evers, D.C., Savoy, L.J., DeSorbo, C.R., Yates, D.E., Hanson, W., Taylor, K.M., Siegel, L.S., Cooley Jr, J.H., Bank, M.S., Major, A., Munney, K., Mower, B.F., Vogel, H.S., Schoh, N., Pokras, M., Goodale, M.W. \& Jeff, F. 2008. Adverse effects from environmental mercury loads on breeding loons. Ecotoxicology 17: 69-81; http://link. springer.com/article/10.1007\%2Fs10646-007-0168-7.

Fowler, J. \& Cohen, L. 1995. Statistics for Ornithologists. Second edition. BTO Guide No 22, British Trust for Ornithology.

Green, M. \& Lindström, Å. 2015. Monitoring population changes in birds of Sweden. Annual report for 2014. Department of Biology, Lund University; in Swedish, summary in English; http://www.fageltaxering.lu.se/sites/default/files/files/Rapporter/arsrapportfor2014kf.pdf.

Hake, M., Dahlgren, T., Åhlund, M., Lindberg, P. \& Eriksson, M.O.G. 2005. The impact of water level fluctuation on the breeding success of the Black-throated Diver Gavia arctica in South-west Sweden. Ornis Fennica 82: 1-12; http://www.projekt-lom.com/Ornis\%20Fennica $\% 2082 \% 201-12$.pdf.

Jackson, D. 2003. Between lake differences in the diet and provisioning behaviour of Black-throated Divers Gavia arctica breeding in Scotland. Ibis 145: 30-44; http://onlinelibrary.wiley.com/doi/10.1046/j.1474919X.2003.00119.x/abstract.

Johnels, A.G., Westermark, T., Berg, W., Persson, P.I. \& Sjöstrand, B. 1967. Pike (Esox lucius L.) and some other aquatic organisms in Sweden as indicators of mercury contamination in the environment. Oikos 18: 323-333; http://www.jstor.org/stable/3565108.

Kauppinen, J. 1993. Densities and habitat distribution of breeding waterfowl in boreal lakes in Finland. Finnish Game Research 48: 24-45.

Kenow, K.P., Hines, R.K., Meyer, M.W., Suarez, S.A. \& Gray, B.R. 2010. Effects of methylmercury exposure on the behavior of captive-reared common loon ( $\mathrm{Ga}$ via immer) chicks. Ecotoxicology 19: 933-944; http:// link.springer.com/article/10.1007/s10646-010-04752\#page-1.

Kenow, K.P., Meyer, M.W., Rossmann, R., Gendron-Fitzpatrick, A. \& Gray, B.R. 2011. Effects of injected methylmercury on the hatching of common loon (Gavia immer) eggs. Ecotoxicology 20: 1684-1693; http://link.springer. com/article/10.1007\%2Fs10646-011-0743-9\#page-1.

Kinnerbäck, A. 2001. Standardiserad metodik för provfiske i sjöar. Fiskeriverket informerar 2001:2; http:// www.slu.se/Documents/externwebben/akvatiska-resurser/Datainsamling/Databasen $\% 20 \mathrm{f} \% \mathrm{C} 3 \% \mathrm{~B} 6 \mathrm{r} \% 20$ 
sj\%C3\%B6provfiske\%20-\%20NORS/Finfo\%202001_2. pdf.

Lehtonen, L. 1970. Zur Biologie des Prachttauchers, Gavia a. $\operatorname{arctica}($ L.). Ann. Zool. Fennici 7: 25-60.

Miller, A., Bignert, A., Porvari, P., Danielsson, S. \& Verta, M. 2013. Mercury in Perch (Perca fluviaitilis) from Sweden and Finland. Water, Air \& Soil Pollution 224: 1472; http:// link.springer.com/article/10.1007\%2Fs11270-013-1472-x.

Monteith, D.T., Stoddard, J.L., Evans, C.D., de Wit, H.A., Forsius, M. Høgåsen, T., Wilander, A., Skjelkvåle, B.L., Jeffries, D.S., Vuorenmaa, J., Keller, B., Kopácek, J. \& Vesely, J. 2007. Dissolved organic carbon trends resulting from changes in atmospheric deposition chemistry. $\mathrm{Na}$ ture 450 (7169): 537-540; http://www.nature.com/nature/ journal/v450/n7169/full/nature06316.html.

Naturvårdsverket 2014. Översyn av nationell akvatisk miljögiftsövervakning. Naturvårdsverket Report 6627; https:// www.naturvardsverket.se/Om-Naturvardsverket/Publikationer/ISBN/6600/978-91-620-6627-7/.

Scheuhemmer, A.M., Meyer, M.W., Sandheinrich, M.B. \& Murray, M.W. 2007. Effects of environmental methylmercury on the health of wild birds, mammals and fish. Ambio 36: 12-18; http://www.jstor.org/discover/10.2307/431578 0 uid $=3738984 \&$ uid $=2129$ \&uid $=2 \&$ uid $=70 \&$ uid $=4 \&$ s $\mathrm{id}=21104103297001$.

Schmutz, J.A., Kimberly, A.T. \& Matz, A.C. 2009. Redthroated Loons (Gavia stellata) breeding in Alaska, USA, are exposed to PCBs while on the wintering grounds. Environmental Pollution 157: 2386-2393; http://www.ncbi. nlm.nih.gov/pubmed/19371988.

Skyllberg, U. 2003. Kvicksilver och metylkvicksilver i mark och vatten - bindning till humus avgörande för miljörisk. Fakta Skog nr 11, 2003; http://www.slu.se/PageFiles/33707/2003/FS03-11.pdf.

Weyhenmeyer, G.A. \& Karlsson, J. 2009. Nonlinear response of dissolved organic carbon concentrations in boreal lakes to increasing temperatures. Limnol. Oceanogr. 54: 2513-2519; http:/www.diva-portal.org/smash/get/ diva2:282560/FULLTEXT01.pdf.

Wilander, A., Johnson, R.K. \& Goedkoop, W. 2003. Riksinventering 2000 - en synoptisk studie i vattenkemi och bottenfauna i svenska sjöar och vattendrag. Inst. för miljöanalys, SLU, rapport 2003:1; http://info1.ma.slu.se/IMA/ Publikationer/internserie/2003-01.pdf.

Åkerblom, S. \& Johansson, K. 2008. Kvicksilver i svensk insjöfisk - variationer i tid och rum. SLU, institutionen för miljöanalys, rapport 2008:8; http://info1.ma.slu.se/IMA/ Publikationer/internserie/2008-08.pdf.

Åkerblom, S., Bignert, A., Meili, M., Sonnesten, L. \& Sundbom, M. 2014. Half a century of changing mercury levels in Swedish freshwater fish. Ambio 43: 91-103; http://ink. springer.com/article/10.1007\%2Fs13280-014-0564-1.

\section{Web-sites Hemsidor}

https://www.artportalen.se/: The Swedish Species Reporting System. Artportalen.

http://data.artsdatabanken.no: The Norwegian Species Information Centra. Artsdatabanken.

http://www.slu.se/sjoprovfiskedatabasen: The national register of survey test-fishing - NORS. Department of Aquatic Resources, Swedish University for Agricultural Sciences. Databasen för provfiske i sjöar - NORS. Institutionen för akvatiska resurser, Sveriges Lantbruksuniversitet. http://infol.ma.slu.se/db.html: The database for the national surveys of lakes and water-courses, Department of Aquatic Sciences and Assessments, Swedish University for Agricultural Sciences. Databas för den nationella miljöövervakningens riksinventering av sjöar och vattendrag, Institutionen för vatten och miljö, Sveriges Lantbruksuniversitet.

http://bd.eionet.europa.eu/article12/: The assessment for the period 2008-2012 of population status and trends of birds under Article 12 of the Birds Directive. Skattningarna för perioden 2008-2012 av populationsstatus och trender hos fågelarter inom EU, $i$ enlighet med artikel 12 i Fågeldirektivet.

\section{Sammanfattning}

Det europeiska beståndet av storlom (utanför Ryssland) består av ungefär 22000 par och av dessa häckar omkring 98\% i Sverige, Finland och Norge. Därför är storlommens europeiska framtid i hög grad beroende av hur arten förvaltas och utvecklas i de nordiska länderna. Mot bakgrund av detta och i kombination med farhågor för en låg ungproduktion tog Sveriges Ornitologiska Förening och Svenska Naturskyddsföreningen 1994 ett gemensamt initiativ genom att starta upp Projekt LOM. En huvuduppgift har varit att initiera och samordna ett fältarbete med syftet att följa häckningsutfallet för både storlommen och smålommen.

Storlommen livnär sig till största delen på fisk och den häckar främst vid näringsfattiga klarvattenssjöar med en i regel gles och artfattig fiskfauna. Även ungarna matas företrädesvis med fisk, men också med vattenlevande insekter under de första levnadsveckorna. Bytesfisken hämtas i regel i häckningssjön, till skillnad från smålommen som häckar vid små och ofta fisktomma tjärnar och gölar och hämtar bytesfisk till ungarna i större klarvattenssjöar - eller i havet vad gäller smålommar häckande utefter Norrlandskusten - på ett pendelavstånd upp till närmare $10 \mathrm{~km}$, ibland längre.

Under de senaste 20 åren har det gått ganska bra för det svenska storlomsbeståndet. I hela landet har ungproduktion legat på en nivå som bedömts balansera den årliga dödligheten, utan någon långsiktig tidstrend. Resultat från Svensk Fågeltaxering antyder en långsiktig ökning av beståndets storlek sedan mitten av 1970-talet, även om trenden kanske har planat ut under senare år. För smålommen är situationen mer bekymmersam, med en ungproduktion som bedömts ligga under nivån för att kompensera för den årliga dödligheten i landets mellersta och södra delar. En sammanfattning av de två lomarternas häckningsutfall i landet under en 20-årsperiod, från 1994 och framåt finns i SOF-BirdLife's årsbok 
"Fågelåret 2013"; http://www.projekt-lom.com/ Projekt.LOM.FAR.2013.pdf.

Den här artikeln fokuseras på storlommen. För även om nivåer och trender i häckningsutfallet och beståndets numerär inte ger anledning till akuta bekymmer, finns det ett oroväckande delresultat efter två decenniers inventeringsarbete; att procentandelen ungkullar med 2-3 ungar har minskat sedan mitten av 1990-talet (Figur 1). Resultatet kan vara en indikation på att ungarnas överlevnad har försämrats. Lommarna lägger i regel två ägg (sällan tre ägg) och oftast kläcks båda äggen, men det är vanligt att bara en av ungarna överlever tills den blir flygg. Vi vet sedan tidigare man att storlomsungarnas överlevnad till stor del är beroende på hur föräldrafåglarna lyckas med att fånga bytesfisk till dem. Därför finns det anledning att anta att en försämrad ungöverlevnad kan vara kopplad till föräldrarnas möjligheter att hitta fisk till ungarna eller födans kvalitet.

Tre tänkbara (och kanske överlappande) förklaringar till att ungarnas överlevnad kan ha försämrats har undersökts:

- Förändrad tillgång på bytesfisk: Den närmast till hands liggande förklaringen är kanske att fiskbestånden kan ha glesats ut och att födounderlaget blivit sämre. Frågan undersöks närmare, på basis av provfiskedata från sjöar där vi inom Projekt LOM har kunnat fastställa regelbunden förekomst av storlom under perioden 1994-2013.

- Förändrade ljusförhållanden i sjöarna: I många sjöar har mängden humusämnen ökat och ljusförhållandena fortlöpande försämrats under senare år, sjöarnas har "brunifierats". Det finns olika uppfattningar om orsaken till denna utveckling, t.ex. en förväntad effekt av att många försurningspåverkade sjöar har återhämtat sig, eller en klimatbetingad påverkan kopplad till stigande temperaturer. Oavsett orsak kan detta ha påverkat förutsättningarna för lommarnas fiske. Lommarna är s.k. visuella predatorer, dvs. att de lokaliserar fiskbytena med synen. Storlommens uppträdande i olika sjöar är kopplad till ljusförhållandena $\mathrm{i}$ vattnet, och ungarnas överlevnad gynnas bland annat av goda siktförhållanden. Här undersöks om det har skett några förändringar i ljusförhållandena i sjöar där vi inom Projekt LOM har kunnat fastställa regelbunden förekomst av storlom under perioden 1994-2013.

- Exponering för kvicksilver: Lommarna är toppkonsumenter i sötvattenssystemen och därför kan man förvänta sig att de är sårbara för exponering av kvicksilver och andra miljögifter som ackumuleras i näringskedjorna. Uppgifter om att halterna av kvicksilver i insjöfisk åter har stigit sedan 1990-talet, efter en successiv minskning sedan 1960-talet, fick för några år sedan en viss uppmärksamhet, men bedömningarna har reviderats under senare år. Vidare var informationen $\mathrm{i}$ första hand baserad på undersökningar av gädda, medan det för storlommens del är mera relevant att studera abborre, som i många sjöar är den viktigaste bytesarten. Men också för abborren är trenden svår att bedöma, och något motstridiga bedömningar har publicerats under senare år. Här har frågan behandlats diskussionsmässigt genom att information om kvicksilverinnehållet av abborre i svenska sjöar har relaterats till bedömningar om risknivåer $\mathrm{i}$ nordamerikanska undersökningar av den närbesläktade arten svartnäbbad islom som i USA och Kanada återfinns i liknande miljöer som där vi träffar på storlommen.

\section{Material och metoder}

På basis av de årliga inventeringarna beräknades ungarnas överlevnad som "procentandelen ungkullar med 2-3 stora ungar", vilket användes som index på överlevnaden till dess de blivit flygga. Med "stora" ungar avses ungar som är minst halvvuxna och att sannolikheten att bli flygg är ganska stor.

I det material som samlats in av Projekt LOM under 20-årsperioden 1994-2013 finns uppgifter om häckande eller stationära par av storlom för åtminstone ett år från drygt 2350 sjöar, eller närmare $10 \%$ av landets cirka 24000 sjöar större än $0,1 \mathrm{~km}^{2}$. För att säkerställa att avstämningar mot databaser för provfisken och information om ljusförhållanden bara innefattat sjöar med regelbunden förekomst av storlom har urvalet av sjöar begränsats till sådana med uppgift om häckande eller stationära par under minst fem år under den aktuella perioden. Närmare 500 sjöar, eller ungefär $2 \%$ av landets sjöar större än $0,1 \mathrm{~km}^{2}$, uppfyllde det kriteriet och för 153 av dessa fanns användbar information om fiskförekomst och/eller ljusförhållanden (detaljer i appendix A). Resultaten har redovisats dels separat för Götaland, Svealand och Norrland.

Bedömningar om fiskförekomsten har gjorts med ledning av provfiskeresultat inom nationell och regional miljöövervakning, som finns samlade i databasen NORS (NatiOnellt Register för Sjöprovfisken, http://www.slu.se/sjoprovfiskedatabasen), för perioden 1994-2013. Medelantalet fiskar per nätansträngning användes som ett relativt mått på fiskförekomsten, och för att undersöka eventuella 
förändringar gjordes parvisa jämförelser av resultaten från provfisken i samma sjöar under 10-årsperioderna 1994-2003 och 2004-2013. Resultaten har redovisats dels för totalfångsten, dels separat för abborre, mörtartad fisk, laxartad fisk och gädda. Uppdelningen betingades bland annat av att ungproduktionen hos storlommen är korrelerad till förekomsten av abborre men inte till andra fiskarter. Skälet till även att redovisa fångsterna av fisk mindre än $22 \mathrm{~cm}$ var att lomungarna sällan kan hantera större fiskbyten. Gädda undersöktes för att kunna bedöma om predationstrycket på små och nykläckta lomungar har förändrats, och då man i tidigare undersökningar har noterat att predation av gäddor kan påverka överlevnaden av lomungar och andungar. Uppgifter från minst ett provfiske vardera under perioderna 1994-2003 och 2004-2013 fanns för 40 sjöar i Götaland och 10 sjöar i Svealand. Däremot fanns användbar information för bara en sjö i Norrland, varför analyser bara har gjorts för Götaland och Svealand (detaljer i appendix B).

För information om ljusförhållandena har i första hand data från den nationella miljöövervakningens riksinventering av sjöar och vattendrag använts. Inom ramen för detta program har ett stort antal sjöar undersökts från 1970-talet och framåt. Resultaten är tillgängliga via en databas vid Institutionen för vatten och miljö vid Sveriges Lantbruksuniversitet, http://infol.ma.slu.se/db.html. För att undersöka eventuella förändringar gjordes parvisa jämförelser av mätningar under perioderna 1994-2003 och 2004-2013 i samma sjöar. I första hand har ljusförhållandena bedömts utifrån absorbans, som är ett mått på genomsläppligheten av ljus i vattnet. Ljusförhållandena påverkas i första hand av mängden löst organsikt material och grumligheten. I den svenska miljöövervakningen används absorbansen av ljus vid våglängden $420 \mathrm{~nm}$ som ett standardiserat mått. En för ögat påtaglig brunfärgning av vattnet upplevs vid en absorbans på ungefär $0,2 \mathrm{f} 420 / 5$. Information om absorbans för perioderna 1994-2003 resp. 2004-2013 fanns för 70 sjöar i Götaland, 43 sjöar i Svealand och 11 sjöar i Norrland. Parallellt har även tillgängliga uppgifter om siktdjup använts, på basis av information från 22 sjöar i Götaland, 7 sjöar i Svealand och bara en sjö i Norrland.

Problematiken kring kvicksilverhalter i fisk och storlomsägg har behandlats diskussionsmässigt och med referenser till tidigare rapporter om kvicksilverinnehållet i lomägg och insjöfisk.

\section{Resultat}

Resultaten kan sammanfattas, som följer:

- Procentandelen ungkullar med 2-3 stora ungar har minskat i hela landet under perioden 19942014 (Figur 1), vilket indikerar en försämrad överlevnad bland ungarna tills de blivit flygga.

- Det finns inga indikationer på att förekomsten av fisk har påtagligt förändrats i storlommens häckningssjöar i södra och mellersta Sverige, även om provfiskeresultaten antyder avsevärda förändringar i enstaka sjöar och bortsett från minskad av förekomst av mörtartad fisk i sjöar i Svealand (Tabell 1, Figur 2, detaljer i appendix B). Resultaten är likartade, vare sig man ser till de totala fångsterna eller enbart till småvuxen fisk $(<22 \mathrm{~cm})$.

- Både absorbans- och siktdjupsvärdena visar att ljusförhållandena har försämrats i storlomssjöarna i Götaland sedan mitten av 1990-talet, men att det inte har varit några liknande förändringar i Svealand och Norrland. Absorbansen har ökat signifikant och med i genomsnitt $16 \%$ i sjöarna i Götaland, medan den legat på samma nivå under hela 20-årsperioden 1994-2013 i Svealand och Norrland (Tabell 2, Figur 3, data för enskilda sjöar i appendix C). Siktdjupet visar en liknande tendens, en genomsnittlig minskning med 23\% från 3,9 m till 3,0 m i Götaland sedan mitten av 1990-talet, medan det legat på kvar samma nivå, 3,5-3,6 m, i Svealand (Tabell 2, Figur 4, data för enskilda sjöar i appendix C).

\section{Diskussion}

Man kan alltså utgå från att den minskade andelen ungkullar med 2-3 stora ungar indikerar en försämrad överlevnad bland storlomsungarna. Att denna utveckling åtminstone inte hittills har resulterat $\mathrm{i}$ en minskad ungproduktion bedöms bero på att det är händelser under ruvningen, såsom predation och översvämmade bon efter stigande vattenstånd, som i första hand påverkar häckningsutfallet. Därför krävs det en ganska omfattande ökning av ungarnas dödlighet innan detta slår igenom i ett försämrat häckningsresultat. Men självfallet kan indikationerna på en minskad andel ungkullar med 2-3 ungar inte negligeras, för om trenden fortsätter kan naturligtvis också ungproduktionen påverkas på sikt. Vidare kanske försämringen indikerar en mer omfattande miljöstörning i flera av landets sjöar.

Det finns emellertid inga indikationer på att den minskade andelen ungkullar med 2-3 ungar kan direkt kopplas till förändringar i fiskförekomsten. 
Speciellt bör man notera att förekomsten av abborre inte har förändrats (Tabell 1, Figur 2), mot bakgrund av att storlommens häckningsutfall i tidigare undersökningar har visat sig vara kopplad till förekomsten av abborre medan man inte har funnit några korrelationer mellan ungproduktionen och förekomsten av övriga fiskarter. Det finns inte heller någon indikation på att förekomsten av gädda har förändrats sedan mitten av 1990-talet, så det är knappast troligt att predationstrycket från gädda på små och nykläckta ungar har förändrats.

Det är också tveksamt om förändrade ljusförhållanden har varit en huvudorsak. Försämrade ljusförhållanden har påvisats i häckningssjöarna i Götaland men inte längre norröver (Tabell 2, Figurerna 3 och 4), trots att andelen ungkullar med 2-3 ungar har minskat även i Svealand och i Norrland (Figur 1). Vad gäller Götaland kan försämrade ljusförhållanden möjligen ha förstärkt en påverkan på ungarnas överlevnad som primärt har orsakats av någon annan faktor.

Eftersom det inte finns några entydiga indikationer på att fiskförekomsten eller ändrade ljusförhållanden har påverkat andelen ungkullar med 2-3 ungar bör fokus riktas mot exponeringen för kvicksilver. Problematiken har uppmärksammats i åtskilliga undersökningar avseende bland annat svartnäbbad islom i Nordamerika. Vad gäller svenska förhållanden noterade man under 1980- och 1990-talen förhöjda halter i storlomsägg insamlade vid häckningssjöar som varit försurningspåverkade, men halterna bedömdes ligga under den nivå där man riskerar en påverkan på reproduktionen.

Eftersom abborren är storlommens viktigaste bytesfisk i många sjöar finns det anledning att se närmare på hur arten exponeras för kvicksilver i svenska sjöar. Abborrar upp till en storlek av ca 12 $\mathrm{cm}$ livnär sig i huvudsak av plankton medan fiskar större än $18 \mathrm{~cm}$ är "rovfiskar" som livnär sig på annan fisk. I en rapport publicerad av Institutionen för miljöanalys vid Sveriges Lantbruksuniversitet 2008 redovisade man bland annat att medianvärdet hos småvuxna och planktonätande abborrar insamlade i slutet av 1990-talet och början av 2000-talet var $0,14 \mathrm{mg} / \mathrm{kg}$ våtvikt, jämfört med $0,20 \mathrm{mg} / \mathrm{kg}$ våtvikt för abborrar i storleksintervallet $12-18 \mathrm{~cm}$ och $0,34 \mathrm{mg} / \mathrm{kg}$ våtvikt för mer storvuxen abborre. Detta ska ställas i relation till resultat från nordamerikanska undersökningar av svartnäbbad islom, där man bedömt att reproduktionen kan reduceras med ca 50\% när bytesfisken har en kvicksilverhalt på $0,21 \mathrm{mg} / \mathrm{kg}$ våtvikt och att den totalt kan slås ut när bytesfisken når en kvicksilverbelastning av $0,41 \mathrm{mg} / \mathrm{kg}$ våtvikt. Med avseende på risk för be- teendestörningar samt nedsatt eller utslagen reproduktion hos svartnäbbad islom har man i nordamerikanska studier föreslagit riktvärden på $0,1,0,18$ respektive $0,4 \mathrm{mg} / \mathrm{kg}$ våtvikt $\mathrm{i}$ bytesfisken. Även om tidstrenden vad gäller kvicksilverinnehållet $i$ abborre är svår att bedöma är det ändå tydligt att storlommens exponering för kvicksilver i svenska sjöar under de senaste årtiondena har legat på en nivå där man inte kan utesluta reproduktionsstörningar. Självfallet tillåter inte den här studien några slutgiliga bedömningar om just exponering för kvicksilver är en huvudorsak till den minskade andelen kullar med 2-3 ungar, men resultaten pekar på att kvicksilverspåret bör prioriteras för fortsatt forskning.

Kvicksilvret och dess effekter har uppmärksammats i miljöarbetet under mer än ett halvsekel. De första kvicksilverlarmen på 1960-talet var kopplade till användningen i bl.a. bekämpningsmedel, men i takt med att begränsningar genom förbud och regleringar har fått genomslag har uppmärksamheten under senare årtionden riktats mot depositionen av luftburet kvicksilver på mark och i vatten. Genom användningen av fossila bränslen tillförs atmosfären kvicksilver som kan transporteras över långa avstånd innan det tvättas ut genom nederbörd eller faller ned som torrdeposition. Över åren och årtiondena har det byggts upp en "pool" av deponerat kvicksilver, bundet till skogs- och torvmark samt sjösediment. Härifrån frigörs kvicksilver till yt- och grundvatten, och det blir därigenom tillgängligt för fisk och andra vattenlevande organismer, i huvudsak som fettlösligt och därmed biotillgängligt metylkvicksilver. Kvicksilvret kan alltså spåras till användning av fossila bränslen, men lokalt påverkas också urlakningen till yt- och grundvatten av markanvändningen och hur skogsbruket bedrivs, och effekterna kan variera lokalt på ett ganska svårförståeligt sätt.

Således påverkas kvicksilverinnehållet i fisk i en enskild sjö på ett ganska komplicerat sätt av vattenkemin såväl som markförhållanden och markanvändningen i tillrinningsområdet. I nordamerikanska undersökningar har man bedömt att risken för bioackumulering av metylerat kvicksilver är störst i näringsfattiga och lågproduktiva sjöar, med $\mathrm{pH}$ värden under 6,0 i kombination med låg alkalinitet och höga halter av löst organiskt material. Inom Projekt LOM har vi bedömt att kanske $10 \%$ av landets häckningssjöar för storlom och mer än $30 \%$ av fiskesjöarna för smålom kan vara sårbara för exponering av kvicksilver som läckt ut från kringliggande skogs- och myrmarker och metylerats. 


\section{Vad göra? - ny kunskap och praktiska åtgärder}

En slutsats från den här studien är att risker kopplade till exponering för kvicksilver bör ges en central plats i förvaltningen av landets insjöar med deras fisk- och fågelbestånd. Och det finns en hel del man kan göra, både vad gäller fortsatta undersökningar och praktiska insatser. Även den som inte upplever fågelskyddet som prioriterat bör ändå inse att den minskade andelen ungkullar med 2-3 ungar kanske indikerar en mer omfattande miljöstörning. I ett stort antal svenska insjöar har abborren idag så höga kvicksilverhalter att de överskrider EU:s direktiv om vattenkvalitetsnormer, och i vissa fall har den bedömts vara olämplig som människoföda. Det är både förvånande och oroande att vi idag inte uppmärksammar insjöfiskens kvalitet, både som fågel- och människoföda, på liknande sätt som i den kvicksilverdebatt vi hade på 1960- och 1970-talen.

Ett fortsatt arbete kan bland annat innehålla:

- Kompletterande insamling och analys av storlomsägg. Tyvärr saknas analysresultat från ägg insamlade efter 1997, så det finns inget underlag för att bedöma om halterna har förändrats under senare år.

- Komplettera miljöövervakningen med analyser av kvicksilverhalter i storlomsägg, baserad på en strikt kontrollerad insamling utförd på ett sätt så att inte häckningsutfallet påverkas. Då kan vi bättre belysa hur toppkonsumenter, storlom såväl som människa, exponeras av kvicksilver via intaget av insjöfisk. I nordamerikanska undersökningar har man visat att resultat baserad på rutinartad insamling och analys av ägg, fjädrar eller blodprover från svartnäbbad islom utgör goda indikatorer på både geografiska skillnader och tidsmässiga trender i tillgängligheten för metylerat kvicksilver för toppredatorer i sötvattensmiljöer. I Naturvårdsverkets nyligen publicerade översyn av nationell akvatisk miljöövervakning (Naturvårdsverkets rapport nr 6627) pekar man bland annat på vikten av fortsatta analyser av hur toppkonsumenter i sötvattensmiljöer exponeras för olika miljögifter.

- Fortsatta ansträngningar att begränsa förbränningen av fossila bränslen. Resultatet från nordamerikanska modelleringsstudier visar att även begränsningar av lokala och regionala utsläpp kan ge positiva effekter.

- Bättre förståelse om hur skogsbruk och annan markanvändning i tillrinningsområdena påver- kar den enskilda sjön, så att man kan ta fram rekommendationer till markägare och skogsbrukare om hur markanvändningen kan anpassas, med syftet att minska negativ miljöpåverkan på sjöar och vattendrag. Berörda myndigheter bör överväga att ta fram instruktioner och allmänna råd på basis av den kunskap som redan finns.

Men även om de indicier vi har idag pekar på att kvicksilverexponeringen på häckningsplatserna måste studeras närmare ska man inte utesluta att lommarnas häckningsutfall också kan påverkas av exponering utanför häckningssjöarna och under flyttning eller övervintring. Exempelvis har man för smålommar häckande i Alaska kunnat relatera ett försämrat häckningsutfall och minskande populationsstorlek till exponering för PCB i marina övervintringsområden i sydöstra Asien. Men man att ställa frågan om eventuell exponering $\mathrm{i}$ häckningsområdena $\mathrm{i}$ motsats till vad fåglarna kan utsättas för under flyttning och övervintring är knappast meningsfullt - observerade reproduktionsstörningar kan vara en kombinerad effekt av exponering av olika ämnen, på skilda platser och under olika tider på året.

\section{Tack}

Studien har tagits fram inom ramen för Projekt LOM, som under perioden 1994-1999 drevs gemensamt av Svenska Naturskyddsföreningen och Sveriges Ornitologiska Förening och därefter som en fristående ideell förening. Uppgifterna om lommarnas häckningsresultat har samlats in genom ett omfattande ideellt arbete. Totalt har sedan starten 1994 över 400 personer medverkat under minst ett år, och under senare år har ungefär 140 personer deltagit. Informationen har kompletterats med avstämningar mot Artportalen, https://www.artportalen.se/. Över åren av ekonomiska bidrag bland annat erhållits från Alvins Fond och Världsnaturfonden-WWF.

Uppgifter om vattenkemiska förhållanden har i första hand hämtats från den nationella miljöövervakningens riksinventering av sjöar och vattendrag via hemsidan för Institutionen för vatten och miljö vid Sveriges Lantbruksuniversitet (http://info1. ma.slu.se/db.html), och information om fiskbestånden i de undersökta sjöarna har erhållits via databasen för provfiske i sjöar (http:/www.slu.se/ sjoprovfiskedatabasen). 
Appendix A. Breeding lakes for Black-throated Diver included in the present study

Häckningssjöar för storlom som ingår $i$ den föreliggande studien.

\begin{tabular}{|c|c|c|c|c|c|c|}
\hline \multirow[t]{2}{*}{$\begin{array}{l}\text { Lake } \\
\text { Sjö }\end{array}$} & \multirow[t]{2}{*}{$\begin{array}{l}\text { County } \\
\text { Län }\end{array}$} & \multicolumn{2}{|c|}{$\begin{array}{c}\text { Coordinates, } \\
\text { RT } 90 \text { national grid } \\
\text { Koordinater, RT } 90 \\
\end{array}$} & \multirow[t]{2}{*}{\begin{tabular}{|c|} 
Gill-net fishing \\
Provfiske \\
Appendix B \\
\end{tabular}} & \multirow[t]{2}{*}{$\begin{array}{l}\text { Absorbance } \\
\text { Absorbans } \\
\text { Appendix C }\end{array}$} & \multirow[t]{2}{*}{$\begin{array}{c}\text { Transparency } \\
\text { Siktdjup } \\
\text { Appendix C } \\
\end{array}$} \\
\hline & & $\mathrm{X}$ & $\mathrm{Y}$ & & & \\
\hline Ivösjön & Skåne & 621669 & 141629 & $\mathrm{X}$ & $\mathrm{X}$ & $\mathrm{X}$ \\
\hline Store Damm & Skåne & 622349 & 135317 & $\mathrm{X}$ & $\mathrm{X}$ & $\mathrm{X}$ \\
\hline Lärkesholmssjön & Skåne & 624178 & 134911 & $\mathrm{X}$ & & $\mathrm{X}$ \\
\hline Immeln & Skåne & 624180 & 141251 & $\mathrm{X}$ & $\mathrm{X}$ & $X$ \\
\hline Värsjö & Skåne & 624606 & 135677 & $\mathrm{X}$ & & $X$ \\
\hline Fedingesjön & Skåne & 625371 & 135680 & & $\mathrm{X}$ & \\
\hline Store Sjö & $\begin{array}{l}\text { Halland, Skåne, } \\
\text { Kronoberg }\end{array}$ & 625762 & 135351 & $\mathrm{X}$ & $\mathrm{X}$ & $\mathrm{X}$ \\
\hline Örsjön / Göinge & Skåne, Kronoberg & 626148 & 138684 & $\mathrm{X}$ & $\mathrm{X}$ & \\
\hline Getsjön & Kronoberg & 626407 & 142157 & $\mathrm{X}$ & & $\mathrm{X}$ \\
\hline Femlingen & Kronoberg & 626855 & 141154 & & $\mathrm{X}$ & \\
\hline Hultebräen & Kalmar & 626971 & 149852 & $\mathrm{X}$ & & $\mathrm{X}$ \\
\hline Torvsjön & Halland & 628971 & 132894 & $\mathrm{X}$ & & \\
\hline Bolmen & $\begin{array}{l}\text { Kronoberg, Jönköping, } \\
\text { Halland }\end{array}$ & 629511 & 136866 & & $\mathrm{X}$ & \\
\hline Stensjö / Madesjö & Kalmar & 630748 & 150410 & $\mathrm{X}$ & & \\
\hline Helgasjön & Kronoberg & 630764 & 143570 & & $\mathrm{X}$ & \\
\hline Knobesholmssjön & Halland & 631164 & 131567 & $\mathrm{X}$ & $\mathrm{X}$ & \\
\hline Vidöstern & Kronoberg, Jönköping & 631841 & 138229 & $\mathrm{X}$ & & \\
\hline Hökasjön / Uppvidinge & Kronoberg & 632741 & 148368 & $\mathrm{X}$ & $\mathrm{X}$ & \\
\hline Lången / Gällaryd & Jönköping & 633118 & 140608 & & $\mathrm{X}$ & \\
\hline Älvasjön / Sibbarp & Halland & 633163 & 130461 & $\mathrm{X}$ & & \\
\hline Skärsjön / Dagsås & Halland & 633344 & 130068 & $\mathrm{X}$ & & $\mathrm{X}$ \\
\hline Björkasjö / Svartrå & Halland & 634338 & 130484 & $\mathrm{X}$ & & \\
\hline Valasjön / Rolfstorp & Halland & 633503 & 130204 & $\mathrm{X}$ & $\mathrm{X}$ & $\mathrm{X}$ \\
\hline Hurven & Jönköping & 633911 & 134035 & $\mathrm{X}$ & $\mathrm{X}$ & $\mathrm{X}$ \\
\hline Stora Iglasjön & Jönköping & 633919 & 135973 & $\mathrm{X}$ & & \\
\hline Svarten & Halland & 634039 & 130685 & $\mathrm{X}$ & & $\mathrm{X}$ \\
\hline Hjärtaredssjön & Halland & 634154 & 131102 & $\mathrm{X}$ & & \\
\hline Stora Neten & Halland & 634378 & 130353 & $\mathrm{X}$ & $\mathrm{X}$ & $\mathrm{X}$ \\
\hline Skällingesjön & Halland & 634467 & 129859 & $\mathrm{X}$ & & \\
\hline Norra Svansjön & Västra Götaland & 634451 & 133674 & & $\mathrm{X}$ & \\
\hline Barken & Halland & 634751 & 130909 & $\mathrm{X}$ & & $\mathrm{X}$ \\
\hline Sävsjön / Arnåsholm & Jönköping & 635030 & 135088 & $\mathrm{X}$ & & $\mathrm{X}$ \\
\hline Fegen & $\begin{array}{l}\text { Västra Götaland, Halland, } \\
\text { Jönköping }\end{array}$ & 635040 & 133900 & & $\mathrm{X}$ & \\
\hline Skärsjön / Karl-Gustav & Halland & 635198 & 130537 & $\mathrm{X}$ & & \\
\hline Majsjön & Jönköping & 635334 & 135239 & $\mathrm{X}$ & & $\mathrm{X}$ \\
\hline Grysjön & Västra Götaland & 636289 & 134951 & & $\mathrm{X}$ & \\
\hline Linnesjön & Jönköping & 636340 & 140067 & $\mathrm{X}$ & & \\
\hline Grumlan & Jönköping & 639394 & 145583 & $\mathrm{X}$ & & \\
\hline Yttre Älvsjön & Västra Götaland & 636452 & 134376 & & $\mathrm{X}$ & \\
\hline Älgsjön / Öxabäck & Västra Götaland & 636479 & 132039 & & $\mathrm{X}$ & \\
\hline Stora Horredsjön & Västra Götaland, Halland & 636512 & 129668 & $\mathrm{X}$ & $X$ & $\mathrm{X}$ \\
\hline Stora Agnsjön & Västra Götaland & 636557 & 129896 & $\mathrm{X}$ & $X$ & \\
\hline Öxasjön & Västra Götaland & 636696 & 131979 & & $\mathrm{X}$ & \\
\hline Lövsjö(n) / Förlanda & Halland & 636911 & 129516 & & $\mathrm{X}$ & \\
\hline Södra Trollsjön & Jönköping & 637156 & 137940 & $\mathrm{X}$ & & $\mathrm{X}$ \\
\hline Kroksjön / Hestra & Jönköping & 637189 & 136703 & $\mathrm{X}$ & & $\mathrm{X}$ \\
\hline Fagerhultasjön & Jönköping & 637469 & 147319 & $\mathrm{X}$ & $\mathrm{X}$ & \\
\hline Lagmanshagasjön & Västra Götaland & 638014 & 136892 & $\mathrm{X}$ & & $\mathrm{X}$ \\
\hline Mycklaflon & Jönköping & 638146 & 146910 & & $\mathrm{X}$ & \\
\hline Bårredsjön & Västra Götaland & 638196 & 130695 & & $\mathrm{X}$ & \\
\hline Nömmen & \begin{tabular}{|l} 
Jönköping \\
\end{tabular} & 638280 & 144298 & $\mathrm{X}$ & & \\
\hline Gissen & Kalmar & 638315 & 150078 & & $\mathrm{X}$ & \\
\hline
\end{tabular}




\begin{tabular}{|c|c|c|c|c|c|c|}
\hline \multirow[t]{2}{*}{$\begin{array}{l}\text { Lake } \\
\text { Sjö }\end{array}$} & \multirow[t]{2}{*}{$\begin{array}{l}\text { County } \\
\text { Län }\end{array}$} & \multicolumn{2}{|c|}{$\begin{array}{c}\text { Coordinates, } \\
\text { RT } 90 \text { national grid } \\
\text { Koordinater, RT } 90\end{array}$} & \multirow[t]{2}{*}{\begin{tabular}{|c|} 
Gill-net fishing \\
Provfiske \\
Appendix B \\
\end{tabular}} & \multirow[t]{2}{*}{$\begin{array}{l}\text { Absorbance } \\
\text { Absorbans } \\
\text { Appendix C }\end{array}$} & \multirow[t]{2}{*}{\begin{tabular}{|l|} 
Transparency \\
Siktdjup \\
Appendix C \\
\end{tabular}} \\
\hline & & $\mathrm{X}$ & Y & & & \\
\hline Skärvingen & Jönköping & 638429 & 144330 & & $\mathrm{X}$ & \\
\hline Fredriksdalasjön & Jönköping & 638919 & 142813 & $\mathrm{X}$ & $\mathrm{X}$ & $\mathrm{X}$ \\
\hline Södra Vixen & Jönköping & 639017 & 144472 & $\mathrm{X}$ & $\mathrm{X}$ & $\mathrm{X}$ \\
\hline Frisjön & Västra Götaland & 639134 & 132882 & & $\mathrm{X}$ & \\
\hline Västra Ingsjön & Västra Götaland & 639243 & 128795 & & $\mathrm{X}$ & \\
\hline Nässjasjön & Jönköping & 639313 & 147403 & & $\mathrm{X}$ & \\
\hline Storsjön / Viskafors & Jönköping & 639330 & 132199 & & $\mathrm{X}$ & \\
\hline Hunsnäsen & Jönköping & 639412 & 145078 & & $\mathrm{X}$ & \\
\hline Finnsjön & Västra Götaland & 639565 & 128173 & & $\mathrm{X}$ & \\
\hline Yxsjön & Västra Götaland & 639716 & 128396 & & $\mathrm{X}$ & \\
\hline $\begin{array}{l}\text { Trehörningen / } \\
\text { Komosse }\end{array}$ & Västra Götaland & 639725 & 137271 & & $\mathrm{X}$ & \\
\hline Viaredssjön & Västra Götaland & 640086 & 131710 & & $\mathrm{X}$ & \\
\hline Hornasjön & Västra Götaland & 640473 & 129112 & & $\mathrm{X}$ & \\
\hline Assjön & Jönköping & 640923 & 145019 & & $\mathrm{X}$ & \\
\hline Strängseredssiön & Västra Götaland & 640979 & 137287 & & $\mathrm{X}$ & \\
\hline Sandsjön / Härryda & Västra Götaland & 640497 & 128906 & & $\mathrm{X}$ & \\
\hline Stora Sturven & Västra Götaland & 640619 & 129618 & & $\mathrm{X}$ & \\
\hline Lilla Härsjön & Västra Götaland & 640768 & 129380 & & $\mathrm{X}$ & \\
\hline Tvärsjön & Västra Götaland & 640773 & 129726 & & $\mathrm{X}$ & \\
\hline Vibosjön & Västra Götaland & 640980 & 130033 & & $\mathrm{X}$ & \\
\hline Uspen & Västra Götaland & 641068 & 129720 & & $\mathrm{X}$ & \\
\hline Västra Lägern & Östergötland, Jönköping & 641225 & 145772 & & $\mathrm{X}$ & \\
\hline Ömmern & Västra Götaland & 641321 & 130445 & & $\mathrm{X}$ & \\
\hline Sälsjön & Västra Götaland & 641649 & 131981 & & $\mathrm{X}$ & \\
\hline Brängen & $\begin{array}{l}\text { Västra Götaland, } \\
\text { Jönköping }\end{array}$ & 641863 & 137912 & & $\mathrm{X}$ & \\
\hline Grosken & Västra Götaland & 642238 & 134651 & & $\mathrm{X}$ & \\
\hline Mullsjön & Jönköping & 642253 & 138588 & & $\mathrm{X}$ & \\
\hline Säven & Västra Götaland & 642608 & 132524 & & $\mathrm{X}$ & \\
\hline Stråken & Jönköping & \begin{tabular}{|l|l|}
042000 \\
642933 \\
\end{tabular} & 138293 & & $\frac{\Lambda}{X}$ & \\
\hline Stora Öjasjön / Hökensås & Västra Götaland & 643887 & 139802 & & $\mathrm{X}$ & \\
\hline Åsunden & Östergötland & 644635 & 149350 & $\mathrm{X}$ & & \\
\hline Järnlunden & Östergötland & 645406 & 149164 & & $\mathrm{X}$ & \\
\hline Store-Väktor & Västra Götaland & 645919 & 127873 & & $\mathrm{X}$ & \\
\hline Viken & Västra Götaland & 649553 & 142029 & & $\mathrm{X}$ & \\
\hline $\begin{array}{l}\text { Stora Holmevatten / } \\
\text { Kynnefjäll }\end{array}$ & Västra Götaland & 651960 & 126392 & & $\mathrm{X}$ & \\
\hline Enaren & Södermanland & 651974 & 159303 & & $\mathrm{X}$ & \\
\hline Skottbackatjärn & Västra Götaland & 653480 & 127241 & & $\mathrm{X}$ & \\
\hline Likstammen & Södermanland & 656531 & 158389 & & $\mathrm{X}$ & \\
\hline Fjättersjön & Stockholm & 653600 & 162119 & & $\mathrm{X}$ & \\
\hline Sottern & Örebro & 654370 & 148479 & & $\mathrm{X}$ & \\
\hline Klämmingen & Södermanland & 655187 & 158633 & & $\mathrm{X}$ & \\
\hline Grindsjön & Stockholm & 655284 & 161919 & & $\mathrm{X}$ & \\
\hline Valsebotjärn & \begin{tabular}{|l|} 
Västra Götaland \\
\end{tabular} & 655651 & 127926 & & $\mathrm{X}$ & \\
\hline Teen & Örebro & 655681 & 143519 & & $\mathrm{X}$ & \\
\hline Acksjön & \begin{tabular}{|l|} 
Södermanland \\
\end{tabular} & 655707 & 155934 & & $\mathrm{X}$ & \\
\hline Lilla Ulvattnet & \begin{tabular}{|l|} 
Västra Götaland \\
\end{tabular} & 655830 & 127145 & & $\mathrm{X}$ & \\
\hline Gravdalssjön & Västra Götaland & \begin{tabular}{|l|}
6550749 \\
65679
\end{tabular} & 127081 & & $\frac{A}{X}$ & \\
\hline Stensjön / Tyresta NP & Stockholm & 656419 & 164404 & $\mathrm{X}$ & & $\mathrm{X}$ \\
\hline Lycksjön & Stockholm & 656550 & 163744 & & $\mathrm{X}$ & \\
\hline Årsjön & Stockholm & 656612 & 164132 & $\mathrm{X}$ & & $\mathrm{X}$ \\
\hline Stora Grytsjön & Södermanland & 656828 & 154713 & $\mathrm{X}$ & & $\mathrm{X}$ \\
\hline Näshultasjön & Södermanland & 656853 & 152800 & & $\mathrm{X}$ & \\
\hline Malmsjön & Stockholm & 656946 & 159871 & & $\mathrm{X}$ & \\
\hline Flaten & Stockholm & 657143 & 163427 & $\mathrm{X}$ & & $\mathrm{X}$ \\
\hline Bornsjön & Stockholm & 657245 & 160890 & & $\mathrm{X}$ & \\
\hline
\end{tabular}




\begin{tabular}{|c|c|c|c|c|c|c|}
\hline \multirow[t]{2}{*}{$\begin{array}{l}\text { Lake } \\
\text { Sjö }\end{array}$} & \multirow[t]{2}{*}{$\begin{array}{l}\text { County } \\
\text { Län }\end{array}$} & \multicolumn{2}{|c|}{$\begin{array}{c}\text { Coordinates, } \\
\text { RT } 90 \text { national grid } \\
\text { Koordinater, RT } 90 \\
\end{array}$} & \multirow[t]{2}{*}{\begin{tabular}{|c|} 
Gill-net fishing \\
Provfiske \\
Appendix B \\
\end{tabular}} & \multirow[t]{2}{*}{$\begin{array}{l}\text { Absorbance } \\
\text { Absorbans } \\
\text { Appendix C }\end{array}$} & \multirow[t]{2}{*}{$\begin{array}{l}\text { Transparency } \\
\text { Siktdjup } \\
\text { Appendix C } \\
\end{array}$} \\
\hline & & $\mathrm{X}$ & $\mathrm{Y}$ & & & \\
\hline Kullaträsket & Stockholm & 657424 & 165233 & & $\mathrm{X}$ & \\
\hline Fiskmyran & Stockholm & 657432 & 164889 & & $\mathrm{X}$ & \\
\hline $\begin{array}{l}\text { Kvarnsjön / } \\
\text { Gustavsberg }\end{array}$ & Stockholm & 658026 & 164732 & & $\mathrm{X}$ & \\
\hline Aspviksträsket & Stockholm & 658291 & 164891 & & $\mathrm{X}$ & \\
\hline Stora Le & $\begin{array}{l}\text { Västra Götaland, } \\
\text { Värmland }\end{array}$ & 658500 & 127455 & & $\mathrm{X}$ & \\
\hline Träsksjön & Stockholm & 658943 & 163638 & $\mathrm{X}$ & $\mathrm{X}$ & \\
\hline Kolsjön & Värmland & 659895 & 131684 & & $\mathrm{X}$ & \\
\hline Lejondalssjön & Stockholm & 660523 & 160785 & & $\mathrm{X}$ & \\
\hline Nedre Hurr & Värmland & 660550 & 127332 & $\mathrm{X}$ & & $\mathrm{X}$ \\
\hline Tärnan & Stockholm & 660688 & 164478 & $\mathrm{X}$ & $\mathrm{X}$ & $\mathrm{X}$ \\
\hline Sirsjön / Älvestorp & Örebro & 660919 & 142948 & & $\mathrm{X}$ & \\
\hline Largen & Stockholm & 661084 & 165433 & & $\mathrm{X}$ & \\
\hline Gryten & Västmanland & 661786 & 151195 & & $\mathrm{X}$ & \\
\hline Vågsjön & Västmanland & 661968 & 150929 & $\mathrm{X}$ & $\mathrm{X}$ & $\mathrm{X}$ \\
\hline Sör-Ẩlgen & Örebro & 662130 & 142921 & & $\mathrm{X}$ & \\
\hline Saxen & Värmland, Örebro & 662551 & 142470 & & $\mathrm{X}$ & \\
\hline Ränken & Värmland & 663277 & 130387 & & $\mathrm{X}$ & \\
\hline Norr-Älgen & Örebro & 663298 & 143149 & & $\mathrm{X}$ & \\
\hline Virsbosjön & Västmanland & 663636 & 151645 & & $\mathrm{X}$ & \\
\hline Örlingen & Örebro & 663823 & 142444 & & $\mathrm{X}$ & \\
\hline Strandsjön & Uppsala & 663926 & 157720 & & $X$ & \\
\hline Erken & Stockholm & 664060 & 165948 & & $\mathrm{X}$ & \\
\hline Ösmaren & Stockholm & 664222 & 166844 & & $\mathrm{X}$ & \\
\hline Hosjön & Uppsala & 664693 & 163935 & & $X$ & \\
\hline Övra Hillen & Dalarna & 667086 & 146907 & $\mathrm{X}$ & & \\
\hline Storljusen & Västmanland & 665508 & 153620 & & $\mathrm{X}$ & \\
\hline Vällen & Uppsala & 666036 & 164166 & & $\mathrm{X}$ & \\
\hline Runn & Dalarna & 670563 & 148814 & & $\mathrm{X}$ & \\
\hline Holmsjön / Kappsjön & Dalarna & 671301 & 138338 & $\mathrm{X}$ & $\mathrm{X}$ & \\
\hline Övre Valsan & Dalarna & 672215 & 147386 & & $\mathrm{X}$ & \\
\hline Öjaren & Gävleborg & 672883 & 155647 & & $\mathrm{X}$ & \\
\hline Siljan & Dalarna & 673490 & 145597 & & $\mathrm{X}$ & \\
\hline $\begin{array}{l}\text { Rönnhällssjön- } \\
\text { Nyckelhällsjön }\end{array}$ & Dalarna & 673719 & 136419 & & $\mathrm{X}$ & \\
\hline Tisjön & Dalarna & 676158 & 129183 & & $\mathrm{X}$ & \\
\hline Orsasjön & Dalarna & 676753 & 142029 & & $\mathrm{X}$ & \\
\hline Bodasjön & Gävleborg & 684897 & 151862 & & $\mathrm{X}$ & \\
\hline Annsjön & Gävleborg & 688945 & 156402 & & $\mathrm{X}$ & \\
\hline Öjen / Njurunda & Västernorrland & 690199 & 158016 & & $\mathrm{X}$ & \\
\hline Vågsfjärden & Västernorrland & 698062 & 162600 & & $\mathrm{X}$ & \\
\hline Solumsjön & Västernorrland & 694401 & 161121 & & $\mathrm{X}$ & \\
\hline Lövsjön / Gallsäter & Västernorrland & 698203 & 161598 & & $\mathrm{X}$ & \\
\hline Mellan-Kroksjön & Västernorrland & 698404 & 157587 & & $\mathrm{X}$ & \\
\hline Lill-Åkersjön & Västernorrland & 699356 & 161439 & $\mathrm{X}$ & & $\mathrm{X}$ \\
\hline Tavelsjön & Västerbotten & 710401 & 171080 & & $\mathrm{X}$ & \\
\hline Storavan & Norrbotten & 728786 & 160756 & & $\mathrm{X}$ & \\
\hline Höträsket / Bergnäset & Norrbotten & 728862 & 179131 & & $\mathrm{X}$ & \\
\hline
\end{tabular}




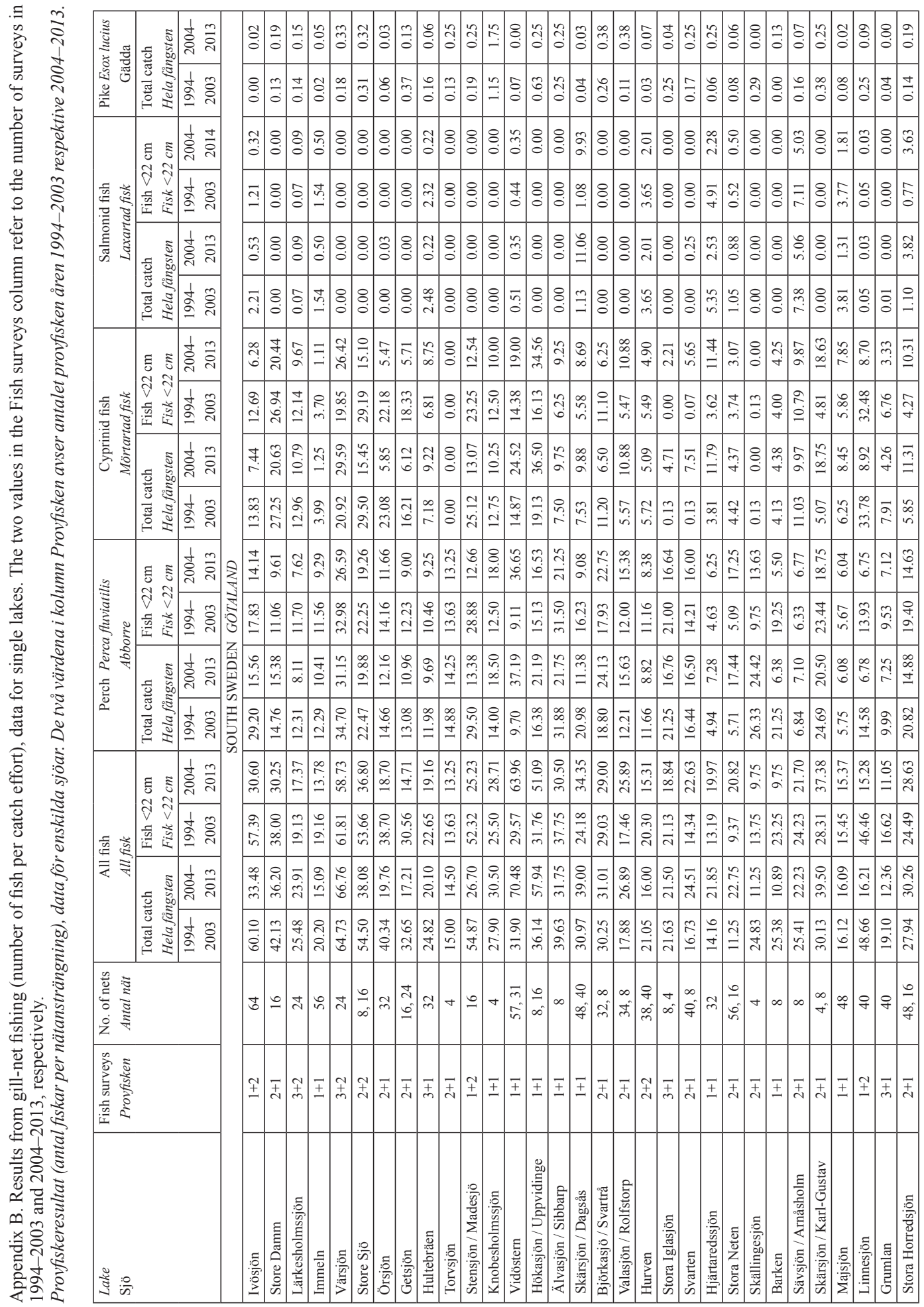




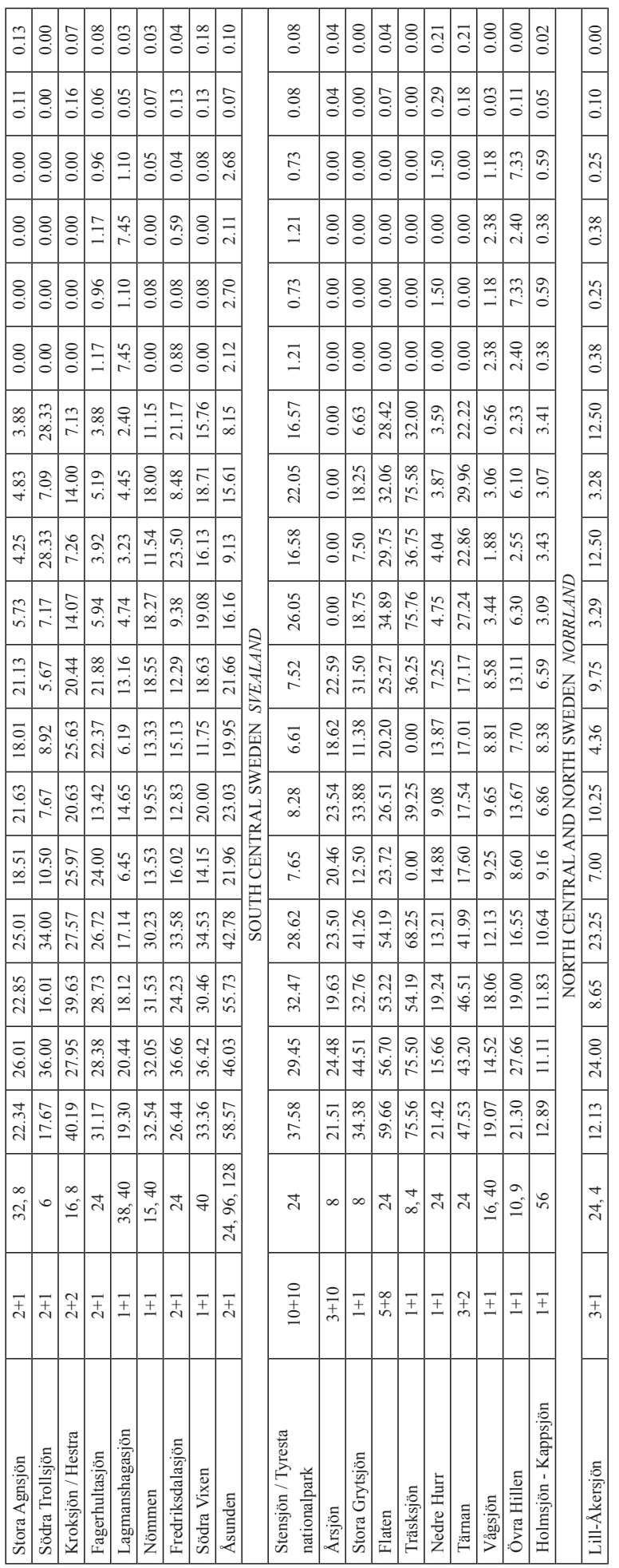


Appendix C. Absorbance and Secchi disc transparency, primary data for single lakes (number of samples in parentheses)

Absorbans och siktdjup, primärdata för enskilda sjöar (antal provtagningar inom parentes).

\begin{tabular}{|c|c|c|c|c|}
\hline \multirow{2}{*}{$\begin{array}{l}\text { Lake } \\
\text { Sjö }\end{array}$} & \multicolumn{2}{|c|}{$\begin{array}{c}\text { Mean absorbance, } \mathrm{f}_{420 / 5} \\
\text { Absorbans, } f_{420 / 5}, \text { medelvärde }\end{array}$} & \multicolumn{2}{|c|}{$\begin{array}{l}\text { Mean Secchi disc transparency } \\
\text { Siktdjup (medelvärde) } m\end{array}$} \\
\hline & $1994-2003$ & $2004-2013$ & 1994-2003 & $2004-2013$ \\
\hline \multicolumn{5}{|c|}{ SOUTH SWEDEN GÖTALAND } \\
\hline Ivösjön & $0.059(2)$ & $0.054(2)$ & $4.5(1)$ & $4.0(1)$ \\
\hline Store Damm & $0.173(1)$ & $0.301(2)$ & $1.5(2)$ & $0.9(1)$ \\
\hline Lärkesholmssjön & - & - & $1.7(3)$ & $1.8(1)$ \\
\hline Immeln & $0.107(1)$ & $0.160(2)$ & $3.9(1)$ & $2.9(1)$ \\
\hline Rössjön & 0.077 (2) & $0.100(2)$ & - & - \\
\hline Värsjö & $0.040(1)$ & $0.085(2)$ & $2.9(3)$ & $3.6(1)$ \\
\hline Fedingesjön & $0.316(2)$ & $0.335(2)$ & - & - \\
\hline Store sjö & $0.208(1)$ & $0.698(3)$ & $1.7(2)$ & $1.2(2)$ \\
\hline Örsjön / Göinge & $0.159(2)$ & $0.253(2)$ & - & - \\
\hline Getsjön & - & - & $2.7(1)$ & $2.8(1)$ \\
\hline Femlingen & $0.236(2)$ & $0.124(1)$ & - & - \\
\hline Hultebräen & - & - & $4.3(3)$ & $4.8(1)$ \\
\hline Åsnen & $0.133(2)$ & $0.103(1)$ & - & - \\
\hline Bolmen & $0.116(2)$ & $0.254(1)$ & - & - \\
\hline Helgasjön & $0.085(2)$ & $0.106(1)$ & - & - \\
\hline Knobesholmssjön & $0.059(1)$ & $0.228(2)$ & - & - \\
\hline Hökasjön & $0.114(2)$ & $0.197(1)$ & - & - \\
\hline Lången / Gällaryd & $0.203(2)$ & $0.233(3)$ & - & $\overline{-}$ \\
\hline Skärsjön / Dagsås & - & - & $8.5(1)$ & $5.2(1)$ \\
\hline Valasjön / Rolfstorp & $0.055(2)$ & $0.043(2)$ & $6.5(2)$ & $4.6(1)$ \\
\hline Hurven & $0.123(2)$ & $0.158(2)$ & $2.8(2)$ & $2.6(1)$ \\
\hline Svarten & - & - & $6.3(2)$ & $3.6(1)$ \\
\hline Stora Neten & $0.037(2)$ & $0.030(1)$ & $10.5(1)$ & $6.8(1)$ \\
\hline Norra Svansjön & $0.109(2)$ & $0.124(1)$ & - & - \\
\hline Barken & - & - & $3.2(1)$ & $2.6(1)$ \\
\hline Sävsjön / Arnåsholm & - & - & $3.5(1)$ & $2.8(1)$ \\
\hline Fegen & $0.155(2)$ & $0.138(1)$ & - & - \\
\hline Majsjön & - & - & $2.9(1)$ & $2.2(1)$ \\
\hline Grysjön & $0.380(2)$ & $0.400(1)$ & - & - \\
\hline Yttre Älvsjön & $0.200(1)$ & $0.220(1)$ & - & $\overline{-}$ \\
\hline Älgsjön / Öxabäck & $0.060(2)$ & $0.050(1)$ & - & - \\
\hline Stora Horredsjön & $0.059(2)$ & $0.018(1)$ & $6.6(2)$ & $4.7(1)$ \\
\hline Stora Agnsjön & $0.102(2)$ & $0.114(1)$ & - & - \\
\hline Öxasjön & $0.170(2)$ & $0.200(1)$ & - & - \\
\hline Lövsjö(n) / Förlanda & $0.036(2)$ & $0.077(2)$ & - & - \\
\hline Södra Trollsjön & - & - & $2.0(2)$ & $1.5(1)$ \\
\hline Kroksjön / Hestra & $\overline{-}$ & $\overline{-}$ & $1.8(2)$ & $1.2(2)$ \\
\hline Fagerhultasjön & $0.171(1)$ & $0.055(2)$ & - & - \\
\hline Lagmanshagasjön & - & - & $1.5(1)$ & $2.0(1)$ \\
\hline Mycklaflon & $0.066(2)$ & $0.027(1)$ & - & - \\
\hline Bårredsjön & $0.210(2)$ & $0.201(3)$ & - & - \\
\hline Gissen & $0.051(2)$ & $0.051(2)$ & - & - \\
\hline Skärvingen & $0.047(2)$ & $0.059(4)$ & - & - \\
\hline Fredriksdalasjön & $0.149(2)$ & $0.133(1)$ & $2.3(2)$ & $2.0(1)$ \\
\hline Södra Vixen & $0.037(2)$ & $0.033(3)$ & $4.9(1)$ & $3.1(1)$ \\
\hline Frisjön & $0.165(2)$ & $0.200(2)$ & - & - \\
\hline
\end{tabular}




\begin{tabular}{|c|c|c|c|c|}
\hline \multirow{2}{*}{$\begin{array}{l}\text { Lake } \\
\text { Sjö }\end{array}$} & \multicolumn{2}{|c|}{$\begin{array}{c}\text { Mean absorbance, } \mathrm{f}_{420 / 5} \\
\text { Absorbans, } f_{420 / 5}, \text { medelvärde }\end{array}$} & \multicolumn{2}{|c|}{$\begin{array}{l}\text { Mean Secchi disc transparency } \\
\text { Siktdjup (medelvärde) } m\end{array}$} \\
\hline & 1994-2003 & $2004-2013$ & 1994-2003 & $2004-2013$ \\
\hline Västra Ingsjön & $0.127(2)$ & $0.153(1)$ & - & - \\
\hline Nässjasjön & $0.282(2)$ & $0.342(3)$ & - & - \\
\hline Storsjön / Viskafors & $0.148(2)$ & $0.196(1)$ & - & - \\
\hline Hunsnäsen & $0.201(2)$ & $0.204(2)$ & - & - \\
\hline Finnsjön & $0.115(2)$ & $0.120(2)$ & - & - \\
\hline Yxsjön / Benareby & $0.106(2)$ & $0.108(1)$ & - & - \\
\hline Trehörningen / Komosse & $0.161(2)$ & $0.144(1)$ & - & - \\
\hline Viaredssjön & $0.122(2)$ & $0.126(1)$ & - & - \\
\hline Hornasjön & $0.180(1)$ & $0.039(2)$ & $\overline{-}$ & $\overline{-}$ \\
\hline Sandsjön / Härryda & $0.085(2)$ & $0.090(1)$ & - & - \\
\hline Stora Sturven & $0.108(2)$ & $0.040(3)$ & - & - \\
\hline Lilla Härsjön & $0.079(2)$ & $0.094(3)$ & $\begin{array}{l}- \\
-\end{array}$ & - \\
\hline Tvärsjön & $0.038(2)$ & $0.079(2)$ & - & - \\
\hline Assjön & $0.034(2)$ & $0.043(3)$ & - & - \\
\hline Strängsredssjön & $0.245(2)$ & $0.267(3)$ & $\begin{array}{l}- \\
-\end{array}$ & - \\
\hline Vibosjön & $0.115(2)$ & $0.110(1)$ & - & - \\
\hline Uspen & $0.065(2)$ & $0.060(1)$ & - & - \\
\hline Västra Lägern & $0.060(2)$ & $0.092(3)$ & $\begin{array}{l}- \\
-\end{array}$ & - \\
\hline Ömmern & $0.047(1)$ & $0.111(2)$ & $\overline{-}$ & $\overline{-}$ \\
\hline Sälsjön & $0.096(2)$ & $0.134(1)$ & - & - \\
\hline Brängen & $0.145(2)$ & $0.146(3)$ & - & - \\
\hline Grosken & $0.141(2)$ & $0.123(1)$ & - & - \\
\hline Mullsjön & $0.066(2)$ & $0.076(3)$ & $\overline{-}$ & $\overline{-}$ \\
\hline Säven & $0.160(2)$ & $0.228(1)$ & - & - \\
\hline Stråken & $0.094(2)$ & $0.138(3)$ & - & - \\
\hline Stora Öjasjön (Hökensås) & $0.067(2)$ & $0.078(3)$ & - & - \\
\hline Järnlunden & $0.057(1)$ & $0.056(1)$ & - & - \\
\hline Store-Väktor & $0.120(2)$ & $0.134(1)$ & - & $\overline{-}$ \\
\hline Viken & $0.086(2)$ & $0.099(2)$ & - & 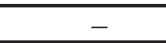 \\
\hline Stora Holmevatten / Kynnefjäll & $0.090(1)$ & $0.102(2)$ & - & - \\
\hline Skottbackatjärn & $0.075(2)$ & $0.060(1)$ & - & - \\
\hline Valsebotjärn & $0.105(2)$ & $0.140(1)$ & - & - \\
\hline Lilla Ulvattnet & $0.190(2)$ & $0.090(1)$ & $\overline{-}$ & $\overline{-}$ \\
\hline Gravdalssjön & $0.039(2)$ & $0.019(2)$ & - & - \\
\hline Stora Le & $0.048(2)$ & $0.050(1)$ & - & - \\
\hline \multicolumn{5}{|c|}{ SOUTH CENTRAL SWEDEN SVEALAND } \\
\hline Enaren & $0.160(2)$ & $0.160(2)$ & - & - \\
\hline Likstammen & $0.033(2)$ & $0.053(1)$ & - & - \\
\hline Fjättersjön & $0.068(2)$ & $0.042(1)$ & - & - \\
\hline Sottern & $0.092(2)$ & $0.053(1)$ & - & - \\
\hline Klämmingen & $0.050(2)$ & $0.041(2)$ & - & $\overline{-}$ \\
\hline Grindsjön & $0.023(2)$ & $0.025(1)$ & $\overline{-}$ & $\overline{-}$ \\
\hline Teen & $0.265(2)$ & $0.209(2)$ & - & - \\
\hline Acksjön (Axsjön) & $0.146(2)$ & $0.122(3)$ & - & - \\
\hline Stensjön / Tyresta nationalpark & - & - & $3.9(10)$ & $3.8(7)$ \\
\hline Lycksjön & $0.155(2)$ & $0.204(1)$ & & \\
\hline Årsjön & - & - & $3.5(3)$ & $3.6(8)$ \\
\hline Stora Grytsjön & - & - & $1.1(1)$ & $1.3(1)$ \\
\hline Näshultasjön & $0.111(2)$ & $0.097(2)$ & - & - \\
\hline
\end{tabular}




\begin{tabular}{|c|c|c|c|c|}
\hline \multirow{2}{*}{$\begin{array}{l}\text { Lake } \\
\text { Sjö }\end{array}$} & \multicolumn{2}{|c|}{$\begin{array}{l}\text { Mean absorbance, } \mathrm{f}_{420 / 5} \\
\text { Absorbans, } f_{420 / 5}, \text { medelvärde }\end{array}$} & \multicolumn{2}{|c|}{$\begin{array}{l}\text { Mean Secchi disc transparency } \\
\text { Siktdjup (medelvärde) } m\end{array}$} \\
\hline & 1994-2003 & 2004-2013 & 1994-2003 & 2004-2013 \\
\hline Malmsjön & $0.061(2)$ & $0.052(2)$ & $\overline{-}$ & - \\
\hline Flaten & - & - & $5.4(5)$ & $6.0(7)$ \\
\hline Bornsjön & $0.028(2)$ & $0.019(1)$ & - & $\begin{array}{llll}- & & & \\
\end{array}$ \\
\hline Kullaträsket & $0.094(2)$ & $0.133(1)$ & - & 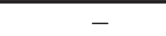 \\
\hline Fiskmyran & $0.146(2)$ & $0.216(1)$ & $\begin{array}{l}- \\
-\end{array}$ & - \\
\hline Kvarnsjön / Gustavsberg & $0.062(1)$ & $0.042(1)$ & - & - \\
\hline Aspviksträsket & $0.060(2)$ & $0.064(1)$ & - & - \\
\hline Träsksjön & $0.059(1)$ & $0.068(2)$ & $\begin{array}{ll}- \\
-\end{array}$ & - \\
\hline Kolsjön & $0.067(1)$ & $0.062(1)$ & $\overline{-}$ & - \\
\hline Lejondalssjön & $0.037(2)$ & $0.022(1)$ & $\begin{array}{ll}- \\
\end{array}$ & - \\
\hline Nedre Hurr & - & - & $2.7(1)$ & $3.4(1)$ \\
\hline Tärnan & $0.067(1)$ & $0.071(2)$ & $3.7(3)$ & $2.8(2)$ \\
\hline Sirsjön / Älvestorp & $0.039(2)$ & $0.041(2)$ & 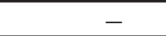 & 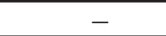 \\
\hline Largen & $0.028(2)$ & $0.021(1)$ & - & - \\
\hline Gryten & $0.126(1)$ & $0.088(1)$ & - & - \\
\hline Vågsjön & $0.091(2)$ & $0.093(1)$ & $4.0(1)$ & $4.5(1)$ \\
\hline Sör-Älgen & $0.095(2)$ & $0.092(2)$ & - & - \\
\hline Saxen & $0.066(2)$ & $0.070(2)$ & $\begin{array}{l}- \\
-\end{array}$ & - \\
\hline Ränken & $0.069(2)$ & $0.117(3)$ & - & $\begin{array}{c}- \\
-\end{array}$ \\
\hline Norr-Älgen & $0.124(2)$ & $0.160(2)$ & $\begin{array}{ll}- \\
-\end{array}$ & - \\
\hline Virsbosjön & $0.051(1)$ & $0.078(1)$ & - & - \\
\hline Örlingen & $0.213(2)$ & $0.188(2)$ & - & - \\
\hline Strandsjön & $0.116(1)$ & $0.168(2)$ & - & - \\
\hline Erken & $0.035(2)$ & $0.036(2)$ & - & - \\
\hline Ösmaren & $0.096(2)$ & $0.054(1)$ & - & - \\
\hline Hosjön & $0.060(2)$ & $0.053(1)$ & - & - \\
\hline Storljusen & $0.056(2)$ & $0.063(3)$ & - & - \\
\hline Vällen & $0.112(2)$ & $0.112(2)$ & - & - \\
\hline Runn & $0.076(2)$ & $0.073(2)$ & - & - \\
\hline Holmsjön / Kappsjön & $0.204(1)$ & $0.162(1)$ & - & - \\
\hline Övre Valsan & $0.077(2)$ & $0.067(2)$ & - & - \\
\hline Siljan & $0.083(2)$ & $0.147(1)$ & - & - \\
\hline Rönnhällsjön-Nyckelhällsjön & $0.176(1)$ & $0.113(2)$ & - & - \\
\hline Tisjön & $0.089(2)$ & $0.080(1)$ & - & - \\
\hline Orsasjön & $0.132(2)$ & $0.136(2)$ & - & - \\
\hline NORT & NTRAL AND & RTH SWEDF & NORRLAND & \\
\hline Öjaren & $0.131(2)$ & $0.137(3)$ & - & - \\
\hline Bodasjön & $0.126(2)$ & $0.081(1)$ & $\begin{array}{l}- \\
-\end{array}$ & - \\
\hline Annsjön & $0.157(2)$ & $0.219(1)$ & - & - \\
\hline Öjen & $0.101(2)$ & $0.153(1)$ & $\begin{array}{ll}- \\
-\end{array}$ & - \\
\hline Solumsjön & $0.200(2)$ & $0.089(3)$ & - & - \\
\hline Vågsfjärden & $0.043(2)$ & $0.040(2)$ & $\begin{array}{l}- \\
-\end{array}$ & - \\
\hline Lövsjön / Gallsäter & $0.117(2)$ & $0.121(1)$ & $\begin{array}{ll}- \\
-\end{array}$ & - \\
\hline Mellan-Kroksjön & $0.183(2)$ & $0.270(3)$ & - & - \\
\hline Lill-Åkersjön & - & - & $4.2(3)$ & $3.5(1)$ \\
\hline Tavelsjön & $0.026(1)$ & $0.031(1)$ & - & - \\
\hline Storavan & $0.013(2)$ & $0.024(2)$ & - & - \\
\hline Höträsket / Bergnäset & $0.044(1)$ & $0.036(1)$ & - & - \\
\hline
\end{tabular}

